\title{
Clinical and radiological characteristics of the cyst of the septum pellucidum in endoscopically treated patients*
}

\section{Kliniczna i radiologiczna charakterystyka torbieli przegrody przeźroczystej u chorych poddanych leczeniu chirurgicznemu z użyciem endoskopu*}

\author{
Klaudyna Kojder \\ Studium Doktoranckie przy Katedrze i Klinice Neurochirurgii Pomorskiego Uniwersytetu Medycznego w Szczecinie \\ ul. Unii Lubelskiej 1, 71-252 Szczecin \\ Kierownik: prof. dr hab. n. med. Ireneusz Kojder
}

\begin{abstract}
SUMMARY
Introduction: The cavum of the septum pellucidum occurs in up to $15 \%$ of adults and is considered as an anatomical variant. However, some patients reveal symptoms which are associated with the evolution from the cavum in the form of a cyst of the septum pellucidum. Cyst incidence is much lower. The pathomechanism and risk factors of such changes are not fully understood. Among the theories for the formation of the cyst, most attention is given to the hypothesis of the mechanism of the valve in the flow of cerebrospinal fluid. However, this statement can be validated only on the basis of direct observation, which can be made in vivo only with the help of the endoscopic method.

The aim of this study was to describe the clinical and radiological features coexisting with the expanding cysts of the septum pellucidum. The research also included considerations on the pathogenesis of the expanding cysts of the septum pellucidum, as well as the evaluation of the intraoperative endoscopic image. Material and methods: The study included 27 patients of the Department of Neurosurgery Pomeranian Medical University in Szczecin, diagnosed with an expanding cyst of the septum pellucidum, who underwent neurosurgery treatment. The patients' clinical and radiological symptoms were evaluated before and after surgical intervention. Analysis of the intraoperative endoscopic images was also performed.
\end{abstract}

Results: The most common clinical symptoms in patients before surgery were similar: headache, dizziness, nausea and vomiting, advanced nervous functions disorders, and visual defects. In most cases the symptoms resolved after surgical treatment, which proves their association with the occurrence of cysts. Significant differences in radiographic measurements before and after surgery where also noted, which allowed the determination of clinical and radiological criteria for the diagnosis of expanding cysts of the septum pellucidum, and intravital intraoperative findings allowed direct proof of the cyst's filling mechanism.

The obtained results allowed us to prove the hypothesis of the valve mechanism as the main factor causing the symptoms in patients with expanding cysts of the septum pellucidum, and to determine the components of the syndrome of the septum pellucidum cyst. They confirmed the validity of the selection of surgical treatment using an endoscope.

Furthermore, changes in the geometry of the structures of the central nervous system observed in the analysis of radiological images before and after surgery made further research on the dynamics of this anatomical area in patients with expanding cysts of the septum pellucidum reasonable.

Key words: neurosurgery, endoscope, cyst of the septum pellucidum, cavum of the septum pellucidum.

\section{STRESZCZENIE}

Wstęp: Jama przegrody przeźroczystej występuje u 15\% osób dorosłych i uznawana jest za wariant normy. U niektórych pacjentów dochodzi do pojawienia się zespołu objawów, który związany jest z ewolucją jamy w postać torbieli. Częstość występowania torbieli jest znacznie niższa. Patomechanizm oraz czynniki ryzyka takiej przemiany nie są dokładnie poznane. Spośród teorii powstawania torbieli współcześnie największą wagę przywiązuje się do hipotezy mechanizmu zastawkowego w przepływie płynu mózgowo-rdzeniowego. Stwierdzenie, iż jest ona prawdziwa może być postawione tylko na podstawie bezpośredniej obserwacji, co umożliwia obecnie przyżyciowo metoda endoskopowa.

Celem pracy było opisanie zespołu cech klinicznych i radiologicznych towarzyszących wypierającej torbieli przegrody przeźroczystej (WTPP). Podjęto także próbę poznania patomechanizmu powstawania WTPP oraz określenia wskazań do leczenia operacyjnego tej patologii.

Materiał i metody: Grupę badanych stanowiło 27 chorych Kliniki Neurochirurgii Pomorskiego Uniwersytetu Medycznego w Szczecinie poddanych leczeniu chirurgicznemu z powodu WTPP. U chorych oceniano objawy kliniczne i radiologiczne przed interwencją i po interwencji chirurgicznej. Analizowano również obraz śródoperacyjny z operacji endoskopowych.

Wyniki: U większości badanych przed leczeniem operacyjnym występowały podobne objawy kliniczne: bóle głowy, zawroty głowy, nudności i wymioty, zaburzenia wyższych czynności nerwowych, zaburzenia widzenia. Po leczeniu operacyjnym stwierdzano ustąpienie dolegliwości w większości przypadków,

* Concise version of doctoral thesis approved by the Council of the Faculte of Medicine, Pomeranian Medical University in Szczecin. Promotor: Leszek Sagan M.D., D.M. Sc. Habil. Original typescript comprises: 66 pages, 38 tables, 24 figures and 70 references.

* Zwięzła wersja rozprawy doktorskiej przyjętej przez Radę Wydziału Lekarsko-Stomatologicznego Pomorskiego Uniwersytetu Medycznego w Szczecinie. Promotor: dr hab. n. med., prof. PUM Leszek Sagan. Maszynopis obejmuje: 66 stron, 38 tabel, 24 ryciny, 70 pozycji piśmiennictwa. 
co dowodzi związku przyczynowego występowania WTPP z wymienionymi objawami. Zauważono również znaczące róż nice w pomiarach radiologicznych przed zabiegiem i po zabiegu, co pozwoliło na wyznaczenie kliniczno-radiologicznych kryteriów rozpoznania WTPP, natomiast przyżyciowe obserwacje śródoperacyjne umożliwiły potwierdzenie mechanizmu napełniania się torbieli.

Wnioski: Uzyskane wyniki badań pozwoliły na udowodnienie hipotezy mechanizmu zastawkowego jako głównego czynnika powodującego powstawanie objawów u chorych z WTPP oraz na określenie składowych zespołu WTPP. Potwierdziły one zasadność wyboru leczenia chirurgicznego za pomocą endoskopu. Ponadto zmiany geometrii struktur centralnego układu nerwowego zaobserwowane podczas analizy obrazów radiologicznych przed zabiegami i po zabiegach chirurgicznych czynią zasadnymi dalsze badania nad dynamiką tego obszaru u chorych z WTPP.

Słowa kluczowe: neurochirurgia, endoskop, torbiel przegrody przeźroczystej, jama przegrody przeźroczystej.

\section{INTRODUCTION}

The original description of the cavum and cyst of the septum pellucidum is attributed to Franciscus de le Boë Sylvius in 1671. Next, Andrea Verga in 1851 described it as a narrow space between two leaves of the septum pellucidum [1, 2, 3]. In 1931, as reported by Pearce and Tubbs et al., Walter Dandy pointed out the need to systematize the knowledge about pathological conditions of the septum pellucidum, indicating basic inconsistencies concerning the problem, such as nomenclature $[2,4]$.

To systematize terminology, in the further part of this work the term cavum septum pellucidum (CSP) will refer to the space identified by computed tomography (CT) or magnetic resonance imaging (MRI), and located within the septum pellucidum (SP) at a parallel position of its walls. The expanding septum pellucidum cyst (ESPC) will be used to define an at least $10 \mathrm{~mm}$-wide fluid-filled space within the septum pellucidum, bulging its walls towards the lateral ventricles of the brain and causing clinical symptoms $[5,6,7]$.

In some reports pathologies of SP are described using either the term cavum or cyst $[2,4]$. For this reason the introduction presents a review of the literature with a focus on the current consensus reached with respect to anatomy, embryology and the occurrence of cava and cysts of the septum pellucidum.

The SP is a midline telencephalic structure. The septum pellucidum is a thin vertical membrane separating the anterior horns of the lateral ventricles of the brain $[2,8,9,10]$. The SP has been described as a triangular sheet between the corpus callosum and the anterior parts of the fornix. Superior, anteroinferior and posteroinferior margins of the septum pellucidum can be distinguished $[2,8,11]$. The SP is attached superiorily to the trunk, anteriorily to the genu, and anteroinferiorily to the rostrum of the corpus callosum. Posteroinferiorily, the SP is attached to the anterior wall of the triangular recess of the third ventricle and fornicolumns $[8,11]$.

The SP is a part of the limbic system of the central nervous system (CNS) [11,12,13]. It is also a part of the entorhinal cortex in the limbic lobe. The limbic lobe is a central part of the entorhinal cortex; its outer zone is formed by the gyrus cinguli, the area subcallosa and the gyrus parahippocampalis, while the inner zone includes the indusium griseum, the gyrus fasciolaris, the gyrus dentatus, the gyri of Retzius, the hippocampus and the septum pellucidum.

\section{WSTĘP}

Jama i torbiel przegrody przeźroczystej zostały po raz pierwszy opisane w 1671 r. przez Franciscusa de le Boë Sylviusa, a następnie przez Andrea Vergę w 1851 r. jako wąska przestrzeń pomiędzy dwoma blaszkami przegrody przeźroczystej $[1,2,3]$. W 1931 r., jak przywołują Pearce oraz Tubbs i wsp., Walter Dandy zwrócił uwagę na konieczność usystematyzowania wiedzy na temat patologii przegrody przeźroczystej, wskazując na nieścisłości dotyczące nawet samego nazewnictwa odnośnie do tego zagadnienia [2, 4].

W celu usystematyzowania używanej terminologii przyjęto, iż w dalszej części pracy termin jama przegrody przeźroczystej (JPP) będzie odnosił się do przestrzeni stwierdzanej badaniem tomografii komputerowej (TK) lub tomografii rezonansu magnetycznego (magnetic resonance imaging - MRI) w obrębie przegrody przeźroczystej (PP), przy zachowaniu równoległego ustawienia jej ścian względem siebie. Natomiast mianem wypierającej torbieli przegrody przeźroczystej (WTPP) określana będzie przestrzeń płynowa o szerokości minimum $10 \mathrm{~mm}$ w obrębie tej przegrody prowadząca do balonowatego uwypuklenia jej ścian w kierunku komór bocznych mózgu i powodująca objawy kliniczne [5, 6, 7].

Część opracowań odnosi się do patologii PP, zamiennie zawierając zarówno termin jama, jak i torbiel [2, 4]. Z tego powodu we wstępie przedstawiona jest analiza piśmiennictwa w trybie współczesnego konsensusu na temat anatomii, embriologii i występowania zarówno jam, jak i torbieli przegrody przeźroczystej.

Przegroda przeźroczysta jest strukturą linii środkowej kresomózgowia. Stanowi ona cienką płytkę, która oddziela od siebie rogi czołowe komór bocznych mózgu [2, 8, 9, 10]. Opisywana jest jako trójkątna błona rozpięta pomiędzy przednimi częściami sklepienia i ciała modzelowatego. Można mówić o brzegu górnym, przednio-dolnym i tylno-dolnym PP [2, 8, 11]. Przegroda przeźroczysta ograniczona jest od góry przez pień, z przodu przez kolano, a w swej przednio-dolnej części przez dziób ciała modzelowatego. Brzeg tylno-dolny graniczy z przednią ścianą zachyłka trójkątnego komory trzeciej oraz ze słupami sklepienia $[8,11]$.

Przegroda przeźroczysta zaliczana jest do układu limbicznego centralnego układu nerwowego (CUN) [11, 12, 13]. Wchodzi też w skład struktur węchomózgowia jako część płata 
The SP and the corpus callosum are attached to the trunk formed by the right and left parts of the fornix. Anteriorily, the trunk runs around the Monroi foramen and splits into two fornicolumns. In the posterior part the trunk splits into two crura fornicis, to which the septum pellucidum is attached. The right and left crura fornicis run around the thalamus and transform into the fimbria of the hippocampus attached to the inferior horn of the lateral ventricle.

The central telencephalon includes the septum pellucidum, the lamina terminalis, the anterior commissure, the corpus callosum, and the fornix commissure $[8,14,15]$.

The lamina terminalis limits the anterior wall of the third ventricle. This thin, frontally positioned lamina is attached superiorily with the rostrum of the corpus callosum, and interiorily runs into the fundus of the ventricle. The posterior surface of the lamina terminalis is covered with ependymal cells. The anterior surface is attached to the piarachnoid, and the subarachnoid space forms at this point the cistern of lamina terminalis.

The anterior commissure is formed by transversely running fibres which at their central part are adjacent to the wall of the third ventricle near the point where the corpus callosum transforms into the lamina terminalis. The anterior part of the anterior commissure is covered by the lamina terminalis.

The hippocampal commissure is formed by the transverse fibres between the crura fornix. In this area the hypothalamic-septal triangle is found, limited by three lines: a line joining the anterior surface of the optic chiasm to the posterior portion of the anterior commissure, a line connecting the posterior commissure to the genu of the rostrum of the corpus callosum, and a line joining the junction of the rostrum with the genu of the corpus callosum to the optic chiasm.

In this triangle and in its boundaries are located: the medial and lateral septal nuclei, the interstitial nucleus of the stria terminalis, the diagonal band of Broca, the accumbens nucleus, the anterior nuclei of hypothalamus, the fibres of the anterior comissure, the fornix columns and portions of the cingulum, the stria terminalis, the stria medullaris of the thalamus, the medial fasciculus of the telencephalon, and fibres associated with the medial olfactory stria [16]. Because of the multiple subcortical nuclei and connections with the hippocampus, this region is considered a part of the septal-hippocampal system [17].

Because of its position, the SP is classified as a medial wall of the brain hemispheres. The two symmetrical leaves that form the SP are composed of the medial (fibrous) and lateral (grey) layers [2, 8, 11].

The grey matter of the septum pellucidum (the ganglion of the septum lucidum, the septofimbrial nucleus) is a posterior process of the lateral septal nuclei located in the true septum [11].

On average, the septum pellucidum is $41 \mathrm{~mm}$ long and $13 \mathrm{~mm}$ high. No larger arteries cross the SP, but it is intersected by 1-3 septal veins [18].

Three anatomical variants of the SP have been identified and were originally described by Liss and Mervis [19]. The first ( $50 \%$ of cases) is the single midline membrane with an ependymal lining on each ventricular surface. The second (25\%) przybrzeżnego. Płat przybrzeżny jest częścią środkową węchomózgowia; jego pas zewnętrzny składa się z zakrętu obręczy, zakrętu podspoidłowego i zakrętu hipokampa, zaś pas wewnętrzny: z nawleczki szarej, zakrętu tasiemeczkowego, zakrętu zębatego, zakrętów Retziusa, hipokampa i właśnie przegrody przeźroczystej.

Przegroda przeźroczysta oraz ciało modzelowate przylegają do trzonu utworzonego ze sklepienia prawego i lewego. Ku przodowi trzon łamie się wokół otworu Monroe i rozdziela na dwa słupy sklepienia. W części tylnej trzon rozdziela się na odnogi sklepienia, pomiędzy którymi rozpięte jest spoidło sklepienia. Odnogi: prawa i lewa łamią się, otaczając wzgórze oraz przechodząc w strzępek hipokampa graniczący z rogiem dolnym komory bocznej.

W kresomózgowiu środkowym poza przegrodą przeźroczystą wyróżnia się także blaszkę krańcową, spoidło przednie, ciało modzelowate, spoidło sklepienia [8, 14, 15].

Blaszka krańcowa ogranicza przednią ścianę komory trzeciej. Cienka, czołowo ustawiona płyta od góry połączona jest z dziobem ciała modzelowatego, zaś u dołu przechodzi w dno komory. Powierzchnia tylna blaszki pokryta jest wyściółką. Powierzchnia przednia zrasta się z oponą miękką, a przestrzeń podpajęczynówkowa tworzy tu zbiornik blaszki krańcowej.

Spoidło przednie tworzą poprzecznie przebiegające włókna, które częścią centralną graniczą ze ścianą komory trzeciej przy przejściu ciała modzelowatego w blaszkę krańcową. Przednią część spoidła przedniego pokrywa blaszka krańcowa.

Spoidło sklepienia tworzą poprzeczne włókna rozpięte między odnogami sklepienia.

W tej okolicy znajduje się trójkąt podwzgórzowo-przegrodowy. Jego obszar wyznaczają trzy linie: 1) idąca grzbietowo od górnej powierzchni skrzyżowania wzrokowego zaraz za spoidło przednie, 2) kierująca się dogłowowo do połączenia dzioba z kolanem oraz 3) wytyczona w kierunku ogonowym do skrzyżowania wzrokowego.

Struktury w obrębie trójkąta i jego najbliższym sąsiedztwie to: pośrodkowe oraz boczne jądra przegrody, jądro łożyskowe prążka krańcowego i prążek przekątny Broca, jądro półleżące, jądra przedniej części podwzgórza, włókna spoidła przedniego, kolumny sklepienia oraz części zakrętu obręczy, prążków krańcowych, prążków rdzennych wzgórza, zakręt pośrodkowy mózgu, włókna związane z prążkiem pośrodkowym węchowym [16]. Z uwagi na dużą liczbę jąder podkorowych i połączeń z formacją hipokampa rejon ten zaliczany jest do systemu przegrodowo-hipokampowego [17].

Z uwagi na położenie PP zaliczana jest do ścian przyśrodkowych półkul mózgu. Dwie symetryczne blaszki, które ją tworzą, składają się z warstwy przyśrodkowej (włóknistej) i bocznej (szarej) $[2,8,11]$.

Istota szara samej PP (zwój septum lucidum, jądro przegrodowo-włókniste) jest tylnym wyrostkiem jąder przegrodowych bocznych zlokalizowanych w przegrodzie prawdziwej [11].

Średnia długość przegrody to $41 \mathrm{~mm}$, średnia wysokość to 13 mm. Przez PP nie przechodzą żadne większe naczynia tętnicze, natomiast przebiegają przez nią 1-3 żyły przegrodowe [18]. 
consists of two separate but closely apposed leaves that delineate a potential space. The third (25\%) is the cavum septum pellucidum in which the leaves of the septum are separated by a space $[2,16,19]$.

The CSP is not connected with the longitudinal cerebral fissure nor with the ventricular system. It is separated by the corpus callosum from the superior portion of the longitudinal cerebral fissure, from the inferior portion by the lamina rostralis and from the third ventricle by the anterior wall of the triangular recess $[8,11,20]$.

Each leaf of the septum pellucidum is both the medial wall of the anterior horn of the lateral ventricle and the lateral wall of the later-formed cavum or cysts, so on one side it adjoins the ependyma [11].

During the formation of the septum pellucidum cyst, the lumen of lateral ventricles may reduce at a normal flow of CSF; in such cases the cyst is visualised very close to the caudate nucleus, especially in imaging with axial sections.

The septum pellucidum forms during the third and fourth months of intrauterine growth, when telencephalic structures differentiate from the anterior portion of the forebrain. Initially, the telencephalon consists of the central part, anteriorily limited by the lamina terminalis, and lateral parts (vesicles) that give rise to symmetrical hemispheres. At this stage the third ventricle forms from the medial part, while vesicles give rise to the lateral ventricles and interventricular foramina. The lamina terminalis gives rise to commissures of the brain. Its superior part transforms into the septal lamina. The inferior part contains fibres that give rise to the anterior commissure and connect the olfactory regions in frontal lobes.

The superior part of the septal lamina transforms into the hippocampal commissure connecting on both sides the hippocampal structure, and in the third month of intrauterine growth it gives rise to fibres that run to the neocortex.

The corpus callosum is a commissure developing at the latest stage. Initially, it runs through the superior part of the septal lamina, but along with the dynamic development of the cortex it enlarges and reaches the anterior part of the hippocampus that flattens up to the indusium griseum. As the development of the corpus callosum progresses, its parts are formed: the rostrum, the genu, the trunk and the splenium of the corpus callosum.

During its caudal elongation, the corpus callosum is involved in the formation of the septum pellucidum, giving rise to its superior and anterior attachments $[4,8,21]$. The CSP is also formed during this process.

The development of the cavum between the leaves of the septum pellucidum initially aroused dispute between supporters of two different hypotheses. As Raybaud concluded, according to the first hypothesis, mainly supported by Zuckerkandl, the cavum of the septum pellucidum was a part of the longitudinal fissure secondarily fused by the developing corpus callosum; the second hypothesis stated that the cavum develops as a secondary fissure in the septal lamina [22]. In 1968 Yakovlev and Rakic concluded from foetal studies that the cavum develops as a result of fusion of the cerebral hemispheres and
Znane są trzy anatomiczne odmiany budowy PP opisane po raz pierwszy przez Liss i Mervis [19]. Połowa przypadków to pojedyncza błona złożona z dwóch sklejonych blaszek, 25\% przypadków to PP utworzona z dwóch blaszek oddzielonych od siebie wąską szczeliną i $25 \%$ przypadków to PP z jamą $[2,16,19]$.

Jama przegrody przeźroczystej nie ma połączenia ze szczeliną podłużną mózgu ani z układem komorowym. Od górnej części szczeliny podłużnej mózgu oddziela ją ciało modzelowate, od dolnej blaszka dziobowa i spoidło przednie, a od komory trzeciej przednia ściana zachyłka trójkątnego [8, 11, 20].

Każda blaszka PP stanowi zarówno ścianę przyśrodkową rogu przedniego komory bocznej, jak i ścianę boczną powstającej później jamy bądź torbieli, co sprawia, że z jednej strony sąsiaduje ona z ependymą [11].

W przebiegu powstawania torbieli PP światło komór bocznych ulegać może zmniejszeniu przy prawidłowym przepływie płynu mózgowo-rdzeniowego (PMR); wówczas uwagę zwraca szczególnie na przekrojach aksjalnych badań obrazowych bliskie sąsiedztwo torbieli z jądrem ogoniastym.

Przegroda przeźroczysta kształtuje się podczas 3. i 4. miesiąca życia płodowego w trakcie różnicowania się struktur kresomózgowia z przedniej części przodomózgowia. Początkowo kresomózgowie składa się z części centralnej, z przodu ograniczonej blaszką krańcową, i części bocznych, pęcherzyków, które w toku rozwoju utworzą symetryczne półkule. Na tym etapie w części środkowej kształtuje się komora trzecia, zaś w pęcherzykach - komory boczne, a także łączące je otwory międzykomorowe. Blaszka krańcowa jest miejscem zawiązywania się spoideł mózgu. Jej górna część przekształca się w tzw. blaszkę spoidłową. Dolna część zawiera włókna, które tworzą spoidło przednie i łączą okolice węchowe płatów czołowych.

Z górnej części blaszki spoidłowej powstaje spoidło sklepienia łączące obustronnie formację hipokampa, a w 3. miesiącu życia płodowego pojawiają się w nim włókna biegnące do kory nowej.

Spoidłem rozwijającym się najpóźniej jest ciało modzelowate. Początkowo przechodzi ono przez górny odcinek blaszki spoidłowej, lecz wraz z coraz bardziej dynamicznym rozwojem kory powiększa się, dochodząc pod przednią część hipokampa, która ulega spłaszczeniu do nawleczki szarej. W trakcie rozwoju ciała modzelowatego formują się poszczególne jego części: dziób, kolano, pień, płat.

Podczas wydłużania się w kierunku ogonowym spoidło wielkie bierze udział w powstawaniu PP, tworząc jej górny i przedni przyczep [4, 8, 21]. W trakcie tego procesu formuje się też JPP.

Proces powstawania jamy między blaszkami PP budził początkowo spory między zwolennikami dwóch odmiennych hipotez. Jak podsumowuje Raybaud, pierwsza z nich, reprezentowana głównie przez Zuckerkandla, przypuszczała, iż JPP była częścią szczeliny podłużnej, zamkniętej wtórnie przez rozwijające się ciało modzelowate; druga grupa uważała, iż jama powstaje jako wtórne pęknięcie w blaszce spoidłowej [22]. W 1968 r. Yakovlev i Rakic stwierdzili w badaniach na płodach ludzkich, iż jama rozwija się na skutek fuzji półkul mózgowych jako kieszeń w przedniej części szczeliny podłużnej [22]. Tak uformowana przestrzeń pomiędzy obiema blaszkami przegrody 
it has the form of a pouch in the anterior part of the longitudinal fissure [22]. The formed space between the two leaves of the septum is originally connected with the longitudinal fissure. At the next stage it is separated by the developing fibres of the rostrum of the corpus callosum. This hypothesis has been supported in studies by Zuckerkandl, Mihalkovics, His and Corning [6, 11, 22, 23, 24, 25].

In recent years, reports have been published about the relationship between the occurrence of a persistent CSP and a mutation in the gene encoding PDGFs - platelet derived growth factors (a tyrosine kinase receptor ligand). PDGFs and their receptors are involved in the development of the lungs, the CNS and the skeleton. Fredriksson et al. demonstrated the relationship of these mutations with the asymmetrical development of the lateral ventricles, septal hypoplasia in mice and the persistent cavum septum pellucidum in humans [26]. However, no correlation was found between the chromosomal anomalies and the occurrence of the persistent CSP in children [27].

In intrauterine life the cavum septum pellucidum connects with the cavum Vergae (a space between the fornix and the trunk of the corpus callosum) by the septal aqueduct (aqueductus caudae septi, aquaeductus ventriculi Vergae, aquaeductus cavi Vergae, aquaeduct septi) [12, 24, 28]. According to some researchers, both cavities are connected during the intrauterine development via small foramina with the lateral ventricles of the brain [15, 29].

The CSP can be visualised ultrasonographically in a 58-mm-long (crown-rump length) [30,31,32], and according to other reports in a $110-\mathrm{mm}$ foetus $[1,33]$. The CSP gradually increases to $27 \mathrm{Hbd}$, remains stable for another several weeks, then in about the sixth month of intrauterine growth begins to close in the caudorostral direction, and the complete closure in most cases occurs in the perinatal period [30, 31, 32]. The regression rate of the CSP varies in homogeneous age groups, and the cavum may still be identified in $37 \%$ of children born at term $[5,23,34]$. A persistent CSP is identified in $2-4 \%$, and up to $15 \%$ of adults [20].

The above controversies surrounding the pathophysiology of ESPC, and the lack of a consistent definition of its clinical and radiographic image gave inspiration to the analysis of these problems. For that purpose the following aims were established:

1. To identify objective and subjective symptoms in patients with ESPC.

2. To identify risk factors of developing a clinical syndrome.

3. To analyse and characterise the radiographic image of ESPC.

4. To analyse intraoperative morphology and outcomes of endoscopic treatment.

\section{MATERIAL AND METHODS}

The analysis was carried out in a group of 27 patients with ESPC surgically treated at the Department of Neurosurgery komunikuje się pierwotnie ze szczeliną podłużną. Następnie zostaje izolowana przez rozwijające się włókna dziobu ciała modzelowatego. Pozostaje to w zgodzie z pracami Zuckerkandla, Mihalkovicsa, Hisa i Corninga [6, 11, 22, 23, 24, 25].

W ostatnich latach pojawiły się doniesienia o związku występowania przetrwałej JPP z mutacją w genie kodującym $P D G F$ - platelet derived growth factors (ligand receptora kinazy tyrozynowej); PDGF i ich receptory biorą udział w kształtowaniu się płuc, CUN i szkieletu. Fredriksson $i$ wsp. dowiedli związku tych mutacji z rozwojem asymetrii komór bocznych, hipoplazją przegrody u myszy i przetrwałą jamą przegrody przeźroczystej u ludzi [26]. Nie stwierdzono natomiast związku defektów chromosomalnych z występowaniem przetrwałej jamy u dzieci [27].

W życiu płodowym JPP łączy się z jamą Vergi (przestrzeń pomiędzy sklepieniem a trzonem ciała modzelowatego) poprzez tzw. wodociąg przegrody (aqueductus caudae septi, aquaeductus ventriculi Vergae, aquaeductus cavi Vergae, aquaeduct septi) [12, 24, 28]. Niektórzy badacze uznają, iż obie jamy komunikują się podczas rozwoju wewnątrzmacicznego przez małe otwory z komorami bocznymi mózgu [15, 29].

Jama przegrody przeźroczystej widoczna jest w badaniu ultrasonograficznym (USG) u 58-milimetrowego (crown-lump lenght, tj. odległość ciemieniowo-siedzeniowa) [30, 31, 32], a wg innych doniesień u 110-milimetrowego płodu [1,33]. Jama przegrody przeźroczystej powiększa się stopniowo do $27 \mathrm{Hbd}$, potem przez kilka tygodni nie zmienia się, a następnie od ok. 6. miesiąca życia płodowego zaczyna zamykać się w kierunku caudo-rostralnym, a jej całkowite zamknięcie w większości przypadków następuje w okresie okołoporodowym [30, 31, 32]. Tempo zanikania jamy jest zróżnicowane w tych samych grupach wiekowych, dlatego stwierdza się ją jeszcze u 37\% dzieci urodzonych o czasie [5, 23, 34]. Przetrwałą JPP stwierdza się u 2-4\% - 15\% dorosłych [20].

Ze względu na przedstawione powyżej kontrowersje co do patofizjologii rozwoju WTPP, a także brak spójnego opisu obrazu klinicznego i radiologicznego, który jej towarzyszy, za zasadne uznano dokonanie analizy tych zagadnień. Dla dokonania takiej oceny wytyczono następujące cele:

1. Opis zaburzeń przedmiotowych i podmiotowych u chorych z WTPP.

2. Opis czynników ryzyka wystąpienia zespołu klinicznego.

3. Analiza i charakterystyka radiologicznego obrazu WTPP.

4. Analiza morfologii śródoperacyjnej i wyników leczenia endoskopowego.

\section{MATERIA I METODY}

Analizie poddano grupę 27 chorych leczonych operacyjnie w Klinice Neurochirurgii i Neurochirurgii Dziecięcej Pomorskiego Uniwersytetu Medycznego w Szczecinie (PUM) z powodu WTPP w latach 2001-2012. Badaną grupę stanowiło 10 kobiet 117 mężczyzn w wieku 5-58 lat. Średnia wieku badanych wynosiła 
Pomeranian Medical University in Szczecin (PMU) between 2001 and 2012. The study group comprised 10 female and 17 male subjects aged $5-58$ years. The mean age of patients was 26.4 years (27.6 years for the female group and 25.24 years for the male group).

Patients' medical records from pre- and postoperative examination by an internist and neurologist, as well as results from laboratory tests and radiographic imaging were analysed. Operative reports were also analysed with a focus on the morphology of the ventricular system and ESPC.

\section{Physical examination and medical interview}

In the medical records of physical examinations and interviews carried out by internists and neurologists special attention was paid to the symptoms of the ESPC syndrome, i.e. headache, dizziness, loss of consciousness, nausea, vomiting, advanced nervous function disorders, epilepsy and visual defects.

Other details were also noted: psychiatric disorders (diagnosed by psychiatrists before the patient's admission to the Department of Neurosurgery PMU), history of injuries, medical interventions and comorbidities.

\section{Radiological examination}

Preoperative and postoperative images from MRI and CT were used to evaluate the size and distance between the selected brain structures. For that purpose, measurements 1-5a were taken from axial sections, measurements 6 from frontal sections, and measurements $7 \mathrm{a}-10$ from sagittal sections. Measurement 1 is the greatest width of the cyst regardless of the layer of the axial section. Measurement 2 is the width of the encephalon measured on the projection of the line connecting the most anterior points of the anterior horns of the lateral ventricles on the axial section. Measurement 3 is the distance between the most extreme points of the anterior horns of the lateral ventricles on the same section as for measurement 1. Measurement 4 is the distance between the inner surface of the wall of an anterior horn of the lateral ventricle and the inner surface of the cyst wall on the right side; it corresponds with the thickness of the cyst wall and ventricle. Measurement $4 \mathrm{a}$ is the distance between the inner surface of the wall of an anterior horn of the lateral ventricle and the inner surface of the cyst wall on the left side; it corresponds with the thickness of the cyst wall and ventricle. Measurement 5 is the distance between the outer surface of the wall of an anterior horn of the lateral ventricle and the inner surface of the cyst wall on the right side; it approximately corresponds with the distance between the cyst and the caput of the caudate nucleus. Measurement 5 a is the distance between the outer surface of the wall of an anterior horn of the lateral ventricle and the inner surface of the cyst wall on the left side; it approximately corresponds with the distance between the cyst and the caput of the caudate nucleus. Measurement 6 was taken to evaluate the width of the Monroi foramen. Measurement $7 \mathrm{a}$ is the distance between the chiasma opticum and the rostrum of the corpus callosum. Measurement $7 \mathrm{~b}$ is the distance between the chiasma opticum and the inner surface of the corpus callosum on the extension
26,4 lat. W grupie kobiet średni wiek wyniósł 27,6lat, w grupie mężczyzn 25,24.

Analizowano dokumentację przed- i pooperacyjną badania internistycznego, neurologicznego, wyniki badań laboratoryjnych oraz radiologicznych. Przeprowadzono także analizę opisów operacji pod kątem morfologii układu komorowego i WTPP.

\section{Badanie podmiotowe i przedmiotowe}

W opisach badań przedmiotowych i podmiotowych w zakresie oceny internistycznej i neurologicznej zwracano szczególną uwagę na elementy mogące stanowić tzw. zespół objawów WTPP, tj.:

- bóle głowy,

- zawroty głowy,

- epizody utraty przytomności,

- nudności, wymioty,

- zaburzenia wyższych czynności nerwowych,

- padaczkę,

- zaburzenia widzenia.

Odnotowywano też szczegóły dotyczące:

- zaburzenia zdrowia psychicznego (choroby z zakresu zdrowia psychicznego zostały rozpoznane przez specjalistę z dziedziny psychiatrii przed przyjęciem do kliniki),

- przebytych urazów,

- przebytych zabiegów,

- chorób współistniejących.

\section{Badanie radiologiczne}

Na podstawie obrazów przed- i pooperacyjnych MRI oraz TK dokonywano oceny dotyczącej wielkości i odległości wybranych struktur mózgowia. W tym zakresie oceniano na przekrojach aksjalnych pomiary 1-5a, natomiast na przekrojach czołowych pomiary 6 oraz na przekrojach strzałkowych pomiary 7a-10. Pomiar 1 to największa szerokość torbieli niezależnie od warstwy przekroju aksjalnego. Pomiar 2 stanowił szerokość mózgowia mierzoną na przedłużeniu linii łączącej najbardziej do przodu wysunięte punkty rogów czołowych komór bocznych, na tym samym przekroju, co pomiar 1 . Pomiar 3 to odległość najdalej oddalonych od siebie punktów rogów czołowych komór bocznych, przekrój tej samej warstwy, co dla pomiaru 1. Pomiar 4 mierzony był od wewnętrznej powierzchni ściany rogu czołowego komory bocznej do wewnętrznej powierzchni ściany torbieli po stronie prawej; w przybliżeniu odpowiada on grubości ściany torbieli i komory. Pomiar 4a zawarty pomiędzy wewnętrzną powierzchnią ściany rogu czołowego komory bocznej a wewnętrzną powierzchnią ściany torbieli po stronie lewej w przybliżeniu odpowiada grubości ściany torbieli i komory. Pomiar 5 to odległość od zewnętrznej powierzchni ściany rogu czołowego komory bocznej do wewnętrznej powierzchni ściany torbieli po stronie prawej; w przybliżeniu odległość torbieli od głowy jądra ogoniastego. Pomiar 5a mierzony od zewnętrznej powierzchni ściany rogu czołowego komory bocznej do wewnętrznej powierzchni ściany torbieli po stronie lewej, co w przybliżeniu jest odległością torbieli od głowy jądra ogoniastego. Pomiar 6 to ocena drożności otworu Monroe. Pomiar 7a to odległość skrzyżowania 
of a line for measurement 7a; it falls in to the ' $z$ ' point, which connects the trunk with the genu of the corpus callosum; its length approximately corresponds with the height of the cyst on the sagittal section. Measurement $7 \mathrm{c}$ is the distance between the ' $z$ ' point and the fornix. Measurement 8 is the width of the genu of the corpus callosum. Measurement 9 is the width of the isthmus of the corpus callosum, and measurement 10 is the width of the splenium of the corpus callosum.

Moreover, to evaluate the influence of ESPC on the structures of the anterior telencephalon the following parameters were estimated: ' $x$ ' parameter, i.e. the ratio of parameter 1 to 3 , ' $y$ ' parameter', i.e. the ratio of parameter 1 to 2 , and ' $z$ ' parameter, i.e. the ratio of parameter 3 to 2 .

\section{Post-operative monitoring}

Within seven days of postoperative hospitalization control MRI or CT imaging of the head were carried out to evaluate treatment outcome and identify potential postoperative complications, such as subdural hygroma or haematoma within the trajectory of the endoscope.

During ambulatory monitoring MRI or CT imaging was performed 6 months after surgical treatment. Further tests were carried out only in patients who presented with symptoms that required diagnostics for control purposes. Findings from these investigations were used for the analysis of postoperative course.

\section{RESULTS}

Patients were hospitalized 8-30 days (mean 12.2 days). Postoperative hospitalization lasted 5-29 days (mean for all patients 8.6 days).

Headache prior to surgical treatment was reported by 27 patients. It was recurrent and on average lasted for 27.17 months before admission to the hospital. In all patients headache involved the whole head, in 2 patients it was more pronounced in the parietal and frontal areas, and in 1 patient in the left temporal area. Headache accompanied by pressure behind the eye was reported by two patients, and with pressure behind the ear by one patient. Frequency of headache was reported as occasional, every 2 weeks or every day.

Dizziness was reported by nine patients. One patient reported loss of consciousness.

Five patients had nausea and vomiting in the preoperative period. One patient reported tinnitus and another one reported nocturia.

Advanced nervous function disorders were found in 5 patients. These included disorders of recent memory in 3 patients, and other memory disorders lasting 2-10 years in 2 patients.

Visual defects were found in 2 patients.

In 2 patients psychiatric disorders (psychotic disorders, obsessive compulsive disorder and ritualistic behaviour) were diagnosed by psychiatrists before the patients' admission to the hospital. wzrokowego od dziobu ciała modzelowatego. Pomiar $7 \mathrm{~b}$ to odległość skrzyżowania wzrokowego od wewnętrznej powierzchni ciała modzelowatego w przedłużeniu linii pomiaru 7a; wypada on w punkcie „z”, który łączy trzon z kolanem ciała modzelowatego; jej wartość w przybliżeniu odpowiada wysokości torbieli na przekroju strzałkowym. Pomiar 7c stanowi odległość od punktu „z” do sklepienia. Pomiar 8 to szerokość ciała modzelowatego w obrębie kolana. Pomiar 9 to szerokość ciała modzelowatego w obrębie cieśni, zaś pomiar 10 to szerokość ciała modzelowatego w obrębie płata.

Dodatkowo celem oceny wpływu WTPP na struktury przedniej części kresomózgowia określano: wskaźnik „x” będący stosunkiem parametru 1 do 3, wskaźnik „y” będący stosunkiem parametru 1 do 2, wskaźnik ,z" będący stosunkiem parametru 3 do 2.

\section{Obserwacja okresu pooperacyjnego}

W trakcie hospitalizacji pooperacyjnej w ciągu 7 dni wykonywano kontrolne badanie MRI lub TK głowy celem oceny efektu leczenia oraz wykluczenia potencjalnych powikłań pooperacyjnych takich jak wodniaki podtwardówkowe lub krwiak w obrębie trajektorii endoskopu.

W okresie obserwacji ambulatoryjnej badanie MRI lub TK wykonywano 6 miesięcy po leczeniu operacyjnym. Kolejne badania wykonywane były jedynie w przypadku wystąpienia objawów wymagających diagnostyki kontrolnej. Powyższy materiał był podstawą do analizy przebiegu pooperacyjnego.

\section{WYNIKI}

Pacjenci hospitalizowani byli 8-30 dni, średnio 12,2 dnia. Liczba dni hospitalizacji po zabiegu zawierała się pomiędzy 5 a 29. Średnia dni hospitalizacji dla wszystkich pacjentów wyniosła 8,6 dnia.

Ból głowy przed leczeniem występował u 27 chorych. Był to ból nawracający. Średnio trwał 27,17 miesięcy przed zgłoszeniem się do szpitala. U wszystkich chorych ból obejmował całą głowę, natomiast bardziej dotyczył okolicy szczy towej i czołowej u 2 chorych, okolicy lewej skroniowej u 1 chorego. Bólowi towarzyszyło uczucie wypychania gałki ocznej w 2 przypadkach, uczucie wypychania małżowiny usznej w 1 przypadku. Częstość występowania bólu wahała się od sporadycznej, poprzez raz na 2 tygodnie, do dolegliwości występujących codziennie.

Zawroty głowy dotyczyły 9 chorych. Utrata przytomności została wspomniana przez 1 chorego. U 5 osób wystąpiły w okresie przedoperacyjnym nudności i wymioty. Jeden chory skarżył się na szumy w uszach. U 1 chorego występowało moczenie nocne.

Zaburzenia wyższych czynności nerwowych dotyczyły 5 osób. W tym zaburzenia pamięci świeżej u 3, inne zaburzenia pamięci przez okres 2 i 10 lat u 2 chorych.

Zaburzenia widzenia występowały w 2 przypadkach.

Zaburzenia zdrowia psychicznego rozpoznane były przed przyjęciem do szpitala przez specjalistów z dziedziny 
Five patients had epileptic seizures in the preoperative period. Four of them had absence type seizures that had been repeating for the last 4-5 years. One patient had a 1.5-year history of quadriplegic convulsions during sleep (2-3 times a month). One patient with a 5-year history of absence type seizures was treated with antiepileptic drugs and achieved transient improvement. Findings from electroencephalography in this patient were abnormal and revealed paroxysmal changes in leads from the posterior part of the right hemisphere, with a tendency to generalized seizures.

Comorbidities were found in eight patients. Three of them had arterial hypertension, 1 had a minor aortal valve defect, and 1 had asymptomatic dilatation of the left ventricular of the heart. One patient reported precocious puberty and malabsorption. Another patient suffered from chronic bronchial asthma. One patient had a history of head injury with loss of consciousness in childhood, as well as gastric and duodenal ulcers. One female patient suffered from ischaemic heart disease (stable cardiac angina), ventricular extrasystoles, hypercholesterolemia, gastric ulcer, functional hyperprolactinemia, Barlow syndrome, lumbar and cervical radiculopathy, sick sinus syndrome, and osteoporosis.

Symptoms associated with ESPC included headache, epileptic seizures, dizziness, nausea, vomiting, psychiatric disorders and advanced nervous function disorders.

\section{Results of radiographic measurements}

Individual measurements, minimum, maximum and median values for the whole group obtained from radiography before and after surgical treatment are presented in Table 1 below. The level of statistical significance was adopted at $\mathrm{p}<0.05$

To analyse statistically significant differences comparable datasets of measurements (before and after surgical treatment) were chosen. Therefore, " $n$ " is variable and different from 27. Statistical analysis was carried out using the Shapiro-Wilk test, t-Student's test and the Wilcoxon's signed-rank test. Results are presented in Table 2 below.

Endoscopic fenestration was used in 19 patients and microsurgical techniques in 8 patients. Navigator system-assisted fenestration was used in 9 out of all 27 cases.

\section{Intraoperative findings}

In all surgically treated patients the cyst wall was significantly bulged within the anterior horns of the lateral ventricles, considerably narrowing their lumen (Fig. 1). In 25 patients the anterior part of the fundus of the cyst had the form of a thin, translucent and pulsating membrane. Minor fissure-like perforations were visible between its wavy layers (Fig. 1a and 1b). The pulsating membrane bulged towards the lumen of the cyst, and the observed fissures became wider. Then the membrane collapsed and the fissures closed. In 2 patients elements of the choroid plexus bulging into the lumen of the cyst through the described part of its fundus were identified. In 2 patients endoscopic fenestration of the discussed anterior part of the abnormal fundus of the cyst was performed to restore connection with the third ventricle of the brain (Fig. 2). psychiatrii u 2 chorych. Były to zaburzenia psychotyczne oraz nerwica natręctw i zachowania rytualne.

U 5 badanych w okresie przed leczeniem występowały napady padaczkowe. $\mathrm{U} 4 \mathrm{z}$ nich były to napady typu absence, powtarzające się od 4 i 5 lat. U 1 osoby od 1,5 roku występowały drgawki czterokończynowe $\mathrm{w}$ trakcie snu, 2-3 razy w miesiącu. U 1 osoby, u której występowały napady typu absence od 5 lat, włączono leczenie przeciwpadaczkowe, co zaskutkowało przejściową poprawą. U tej osoby elektroencefalografia okazała się nieprawidłowa, wykazując zmiany napadowe w odprowadzeniach z tylnych części prawej półkuli mózgu $\mathrm{z}$ tendencją do uogólniania się.

Choroby współistniejące występowały u 8 badanych. Troje cierpiało na nadciśnienie tętnicze, u 1 stwierdzono wadę aortalną małego stopnia, u innego poszerzenie lewej komory serca, bezobjawowe. U $1 \mathrm{z}$ chorych w wywiadzie stwierdzono przedwczesne dojrzewanie i zaburzenia wchłaniania. Inny badany chorował przewlekle na astmę oskrzelową. Jeden chory w wieku dziecięcym przebył uraz głowy z utratą świadomości; u niego też wystąpiła choroba wrzodowa żołądka i dwunastnicy. Jedna badana cierpiała na chorobę niedokrwienną serca pod postacią dławicy sercowej stabilnej, ekstrasystolie komorowe, hipercholesterolemię, chorobę wrzodową żołądka, hyperprolaktynemię czynnościową, zespół Barlowa, radikulopatię odcinka lędźwiowego i szyjnego kręgosłupa, zespół chorej zatoki, osteoporozę.

Objawy towarzyszące WTPP to: ból, napady padaczkowe, zawroty głowy, nudności, wymioty, zaburzenia zdrowia psychicznego, zaburzenia wyższych czynności nerwowych.

\section{Wyniki pomiarów badań radiologicznych}

Poszczególne pomiary, wartości minimalne, maksymalne oraz mediany dla całej grupy w badaniach obrazowych przed i po leczeniu operacyjnym zostały przedstawione w tabeli 1.

Dla analizy statystycznej przyjęto istotność statystyczną, gdzie $\mathrm{p}<0,05$.

Do określenia różnic istotnych statystycznie wybrano porównywane liczebnie grupy pomiarów - przed i po leczeniu operacyjnym. Stąd zmienna i różna od 27 liczba „n”.

W analizie statystycznej uży to testów Shapiro-Wilka, testu t-Studenta oraz testu koleracji par Wilcoxona. Wyniki zawarto w tabeli 2 .

U 19 chorych zastosowano endoskopową fenestrację, u pozostałych metodę mikrochirurgiczną i u 9 neuronawigacyjne wspomaganie.

\section{Wyniki obserwacji śródoperacyjnych}

We wszystkich przypadkach operowanych chorych ściany torbieli znacznie uwypuklały się w obrębie rogów czołowych komór bocznych, zwężając znacznie ich światło (ryc. 1). W 25 przypadkach przednia część dna torbieli miała charakter cienkiej, przeziernej i pulsującej błony (ryc. 1a, ryc. 1b). Pomiędzy jej falującymi warstwami dostrzegalne były niewielkie perforacje w kształcie szczelin. W trakcie pulsowania błona wpuklała się do światła torbieli, a obserwowane szczeliny ulegały poszerzeniu, następnie błona zapadała się, co prowadziło 
TABLE 1. Results of radiographic measurements before and after surgery TABELA 1. Pomiary radiologiczne przed zabiegiem i po zabiegu operacyjnym

\begin{tabular}{|c|c|c|c|c|c|c|}
\hline \multirow{2}{*}{$\begin{array}{l}\text { No. } \\
\text { Lp. }\end{array}$} & \multicolumn{3}{|c|}{$\begin{array}{c}\text { Before surgery } \\
\text { Pomiary przed zabiegiem }\end{array}$} & \multicolumn{3}{|c|}{$\begin{array}{c}\text { After surgery } \\
\text { Pomiary po zabiegu }\end{array}$} \\
\hline & minumum & $\begin{array}{l}\text { maximum } \\
\text { maksimum }\end{array}$ & $\begin{array}{l}\text { median } \\
\text { mediana }\end{array}$ & minimum & $\begin{array}{l}\text { maximum } \\
\text { maksimum }\end{array}$ & $\begin{array}{l}\text { median } \\
\text { mediana }\end{array}$ \\
\hline 1 & 5,3 & 36,98 & 13,84 & 5,91 & 13,91 & 10,16 \\
\hline 2 & 81,95 & 160 & 111,48 & 106,03 & 124,71 & 108,96 \\
\hline 3 & 24,76 & 51,33 & 37,65 & 31,05 & 44,74 & 39,48 \\
\hline$x$ & 0,2 & 0,74 & 0,35 & 0,15 & 0,35 & 0,26 \\
\hline$y$ & 0,05 & 0,33 & 0,12 & 0,05 & 0,13 & 0,09 \\
\hline$z$ & 0,27 & 0,45 & 0,33 & 0,31 & 0,41 & 0,35 \\
\hline 4 & 0 & 2,33 & 1,29 & 1,12 & 3,19 & 2,07 \\
\hline $4 a$ & 0 & 2,67 & 1,54 & 0,83 & 2,74 & 1,84 \\
\hline 5 & 0,89 & 5,3 & 3,14 & 1,85 & 7,83 & 5,47 \\
\hline 6 & - & - & - & - & - & - \\
\hline $7 a$ & 10,43 & 37,38 & 17,31 & 15,35 & 21,56 & 18,15 \\
\hline $7 b$ & 26,18 & 50 & 35,71 & 31,77 & 33,5 & 33,34 \\
\hline $7 c$ & 13,42 & 40,26 & 17,65 & 14,71 & 16,32 & 15,37 \\
\hline $7 d$ & 14,34 & 24,25 & 19,31 & 11,78 & 18,15 & 13,62 \\
\hline 8 & 2,11 & 15 & 7,13 & 9,99 & 10,5 & 10,23 \\
\hline 9 & 2,1 & 5,85 & 3,89 & 3,83 & 5,85 & 5,66 \\
\hline 10 & 3,79 & 25 & 9,38 & 11,85 & 14,77 & 11,91 \\
\hline
\end{tabular}

TABLE 2. Measurements before and after the surgery and the results of the statistical analysis

TABELA 2. Porównanie pomiarów przed zabiegiem i po zabiegu operacyjnym, wyniki analizy statystycznej

\begin{tabular}{|c|c|c|c|c|c|}
\hline $\begin{array}{l}\text { Measurement } \\
\text { No. } \\
\text { Pomiar nr }\end{array}$ & $\begin{array}{c}\text { No of measurements } \\
\text { before surgery } \\
\mathrm{n} \text { badanych przed } \\
\text { zabiegiem }\end{array}$ & $\begin{array}{c}\text { No of measurements } \\
\text { after surgery } \\
\mathrm{n} \text { badanych } \\
\text { po zabiegu }\end{array}$ & $\begin{array}{c}\text { Median } \\
\text { (before surgery) } \\
\text { Mediana } \\
\text { (przed zabiegiem) }\end{array}$ & $\begin{array}{c}\text { Median } \\
\text { (after surgery) } \\
\text { Mediana } \\
\text { (po zabiegu) }\end{array}$ & $\begin{array}{l}\text { Statistic significance } \\
\text { Poziom istotności } \\
\text { statystycznej }\end{array}$ \\
\hline 1 & 9 & 9 & 14,09 & 10,17 & $\begin{array}{c}\text { Significant } \\
\text { Różnica istotna statystycznie }\end{array}$ \\
\hline 2 & 9 & 9 & 110,11 & 108,96 & NS \\
\hline$x$ & 9 & 9 & 0,35 & 0,29 & $\begin{array}{c}\text { Significant } \\
\text { Różnica istotna statystycznie }\end{array}$ \\
\hline $\mathrm{y}$ & 9 & 9 & 0,12 & 0,09 & $\begin{array}{c}\text { Significant } \\
\text { Różnica istotna statystycznie }\end{array}$ \\
\hline Z & 9 & 9 & 0,34 & 0,34 & NS \\
\hline 4 & 9 & 9 & 1,37 & 2,03 & $\begin{array}{c}\text { Significant } \\
\text { Różnica istotna statystycznie }\end{array}$ \\
\hline $4 a$ & 9 & 9 & 1,58 & 1,78 & NS \\
\hline 5 & 9 & 9 & 2,74 & 5,15 & $\begin{array}{c}\text { Significant } \\
\text { Różnica istotna statystycznie }\end{array}$ \\
\hline $5 a$ & 9 & 9 & 2,43 & 4,87 & $\begin{array}{c}\text { Significant } \\
\text { Różnica istotna statystycznie }\end{array}$ \\
\hline $7 a$ & 6 & 2 & 16,8 & 18,46 & - \\
\hline $7 b$ & 6 & 2 & 34,98 & 33,42 & - \\
\hline $7 c$ & 6 & 2 & 18,61 & 15,52 & - \\
\hline 8 & 6 & 2 & 9,18 & 10,25 & - \\
\hline 9 & 6 & 2 & 4,6 & 4,75 & - \\
\hline 10 & 6 & 2 & 12,88 & 13,31 & - \\
\hline
\end{tabular}



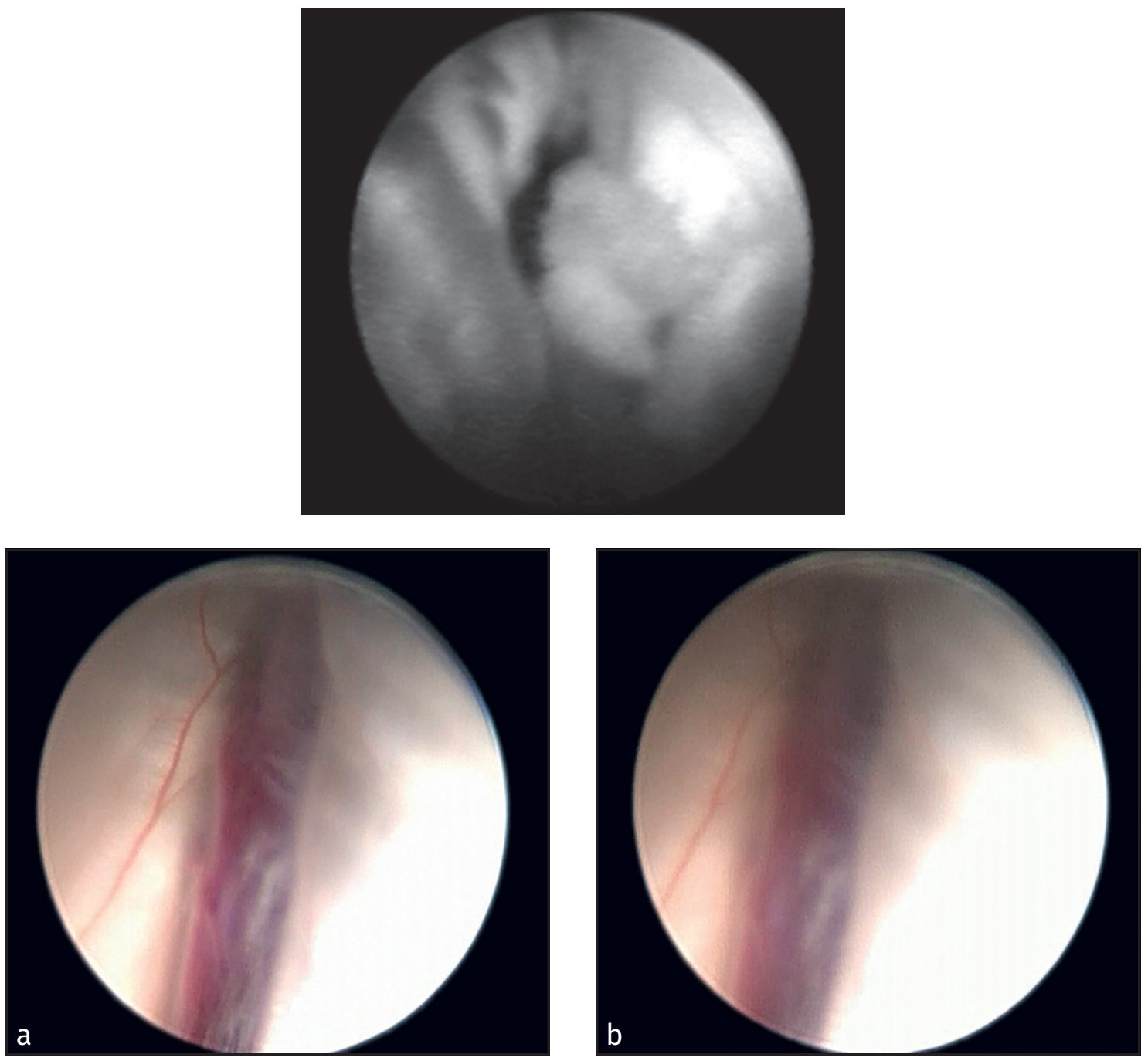

FIGURE 1. Constricted Monroi foramen (the choroid plexus bulging into the lumen of the cyst on the right side): a) minor fissure-like perforations visible between membrane's wavy layers; b) the pulsating membrane and the observed fissures with CSF jets

RYCINA 1. Zwężony otwór Monro (po prawej wpuklający się w światło torbieli splot naczyniówkowy): a) pomiędzy falującymi warstwami dostrzegalne niewielkie perforacje w kształcie szczelin; b) pulsująca błona i obserwowane szczeliny z dżetem płynu mózgowo-rdzeniowego

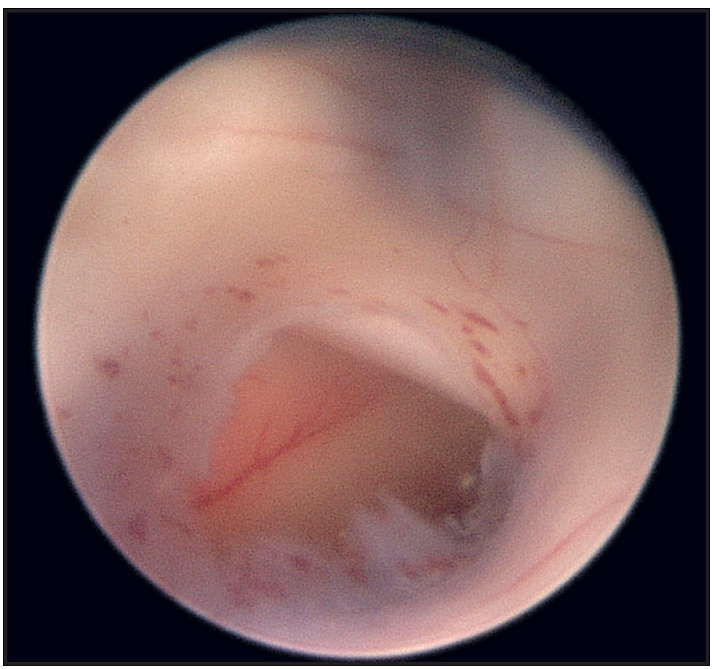

FIGURE 2. Fundus of the cyst after fenestration (lumen of the third ventricle in the background) RYCINA 2. Dno torbieli po fenestracji (w głębi widoczne światło III komory) 


\section{Postoperative findings}

The postoperative monitoring lasted between 6 months and 11 years (mean 4.5 years). In 23 patients headache subsided completely. In another 4 patients it occurred occasionally, but it was very mild and of another nature than the preoperative headache.

Preoperatively diagnosed disorders of recent memory resolved in 4 out of 5 patients. In one case recent memory deteriorated after surgical treatment (60\% vs 70\% score in preoperative examination). In this patient, a 4-year postoperative monitoring revealed a significant improvement with respect to the preoperative deficit, but minor memory disorders persisted (85\%).

In 1 patient the caput of the caudate nucleus was accidentally penetrated during the insertion of an endoscope into the narrow lateral ventricle. Postoperatively this patient was diagnosed with a tendency to spastic hemiparesis that subsided completely within the following 6 months.

\section{Analysis of results}

In the study group 7 patients were aged 0-15 years, 9 patients were aged 16-25 years, and 11 patients were older than 25 years. In the female group this proportion was respectively 3,3 and 4 , and in the male group 4, 6 and 7.

The population of patients with CSP in a breakdown by sex and age is presented in Table 3 below.

TABLE 3. Study population in a breakdown by sex and age; in $\%$ TABELA 3. Procentowy skład grup z podziałem na płeć, względem wieku

\begin{tabular}{lcccccc}
$\begin{array}{l}\text { Age (years) } \\
\text { Wiek (lata) }\end{array}$ & $\begin{array}{c}\text { Total (n) } \\
\text { Razem (n) }\end{array}$ & $\begin{array}{c}\text { Total (\%) } \\
\text { Razem (\%) }\end{array}$ & $\begin{array}{c}\mathrm{F}(\mathrm{n}) \\
\mathrm{K}(\mathrm{n})\end{array}$ & $\begin{array}{c}\mathrm{F}(\%) \\
\mathrm{K}(\%)\end{array}$ & $\begin{array}{c}\text { M } \\
(\mathrm{n})\end{array}$ & $\begin{array}{c}\text { M } \\
(\%)\end{array}$ \\
\hline $0-15$ & 7 & 25 & 3 & 30 & 4 & 24 \\
\hline $16-25$ & 9 & 31 & 3 & 30 & 6 & 35 \\
\hline$>25$ & 11 & 44 & 4 & 40 & 7 & 41 \\
\hline
\end{tabular}

\section{Preoperative and postoperative symptoms in patients with cavum septum pellucidum}

The most frequent subjective symptom reported by patients was a generalised headache (1), distending and located on both sides in the frontal and temporal area, or behind the eyes. Headache was reported by all patients. Dizziness was the second most frequent symptom $-22 \%$ (2). Other symptoms occurred with a similar frequency (19\% of cases): nausea and/or vomiting (3), cognitive disorders (4) and epilepsy (5). Psychiatric disorders (6) were diagnosed in 7 patients. Tinnitus (7) was reported by 4 patients. Visual defects (8) were found in 4 patients, similar to the loss of consciousness (9). Statistics are presented in Figure 3 below.

Symptoms that resolved after surgical treatment were: headache, nausea, vomiting, dizziness and advanced nervous function disorders.

\section{Analysis of the radiographic image of cavum septum pellucidum in surgically treated patients}

The preoperative analysis of images from MR demonstrated a potential connection between the lumen of the cyst and either do zamykania szczelin. W 2 przypadkach stwierdzano elementy splotu naczyniówkowego wpuklające się do światła torbieli przez opisywaną część jej dna. W 2 przypadkach wykonano endoskopową fenestrację omawianej przedniej części zmienionego dna torbieli, udrażniając ją do III komory mózgu (ryc. 2).

\section{Wyniki obserwacji pooperacyjnych}

Okres obserwacji pooperacyjnej wynosił od 6 miesięcy do 11 lat (średnia 4,5 roku). W 23 przy padkach ból głowy wycofał się całkowicie, a w 4 pojawiał się sporadycznie, miał bardzo małą intensywność oraz inny charakter niż przedoperacyjny.

W grupie 5 chorych z przedoperacyjnie stwierdzanymi zaburzeniami pamięci świeżej we wszystkich przypadkach oprócz 1 doszło do wycofania się tych zaburzeń. W 1 przypadku (chory K.J.) pamięć świeża pogorszyła się po leczeniu operacyjnym (60\% w porównaniu do $70 \%$ w badaniu przedoperacyjnym). Podczas 4-letniej obserwacji pooperacyjnej stwierdzono u niego znaczną poprawę w stosunku do deficytu przedoperacyjnego, jednak niewielkie zaburzenia w tym zakresie utrzymywały się (85\%).

W 1 przypadku w trakcie wprowadzania endoskopu do wąskiej komory bocznej doszło do penetracji w obrębie głowy jądra ogoniastego. Pooperacyjnie u tego chorego stwierdzono tendencję do niedowładu spastycznego połowiczego, który w ciągu 6 miesięcy wycofał się całkowicie.

\section{Omówienie wyników}

Wśród całej grupy badanych 7 osób było w przedziale wieku 0-15 lat, 9 osób - 16-25 lat i 11 osób liczyło >25 lat. Dla grupy kobiet liczby te analogiczne wynosiły: 3, 3 i 4 osoby, dla grupy mężczyzn: 4, 6 i 7 osób w poszczególnych podgrupach. Procentowy skład grup chorych z torbielą przegrody przeźroczystej (TPP) z podziałem na płeć względem wieku przedstawiono w tabeli 3 .

\section{Omówienie symptomatyki przed operacją i po operacji u pacjentów z torbielą przegrody przeźroczystej}

Najczęstszym objawem przedmiotowym był uogólniony ból głowy (1) o charakterze wypierającym, zlokalizowany obustronnie w okolicy czołowo-skroniowej lub za gałkami ocznymi. Występował on we wszystkich przypadkach. Drugim najczęstszym objawem występującym w 22\% przypadków były zawroty głowy (2). Podobnie często, bo w 19\% przypadków występowały nudności lub wymioty (3), zaburzenia intelektualne (4) i epilepsja (5). Zaburzenia zdrowia psychicznego (6) dotyczyły 7 chorych. Szumy w uszach (7) zgłaszało 4 chorych. Zaburzenia widzenia (8) odnotowano u 4 chorych, podobnie jak utratę przytomności (9). Dane przedstawiono na rycinie 3.

Spośród wymienionych objawów po zabiegach operacyjnych stwierdzono ustąpienie: bólów głowy, nudności, wymiotów, zawrotów głowy, zaburzeń wyższych czynności nerwowych.

\section{Omówienie obrazu radiologicznego $\mathrm{z}$ torbielą przegrody przeźroczystej u pacjentów operowanych}

Ocena przedoperacyjnych obrazów MRI wykazała potencjalną komunikację światła torbieli poprzez przednią część jej ściany 


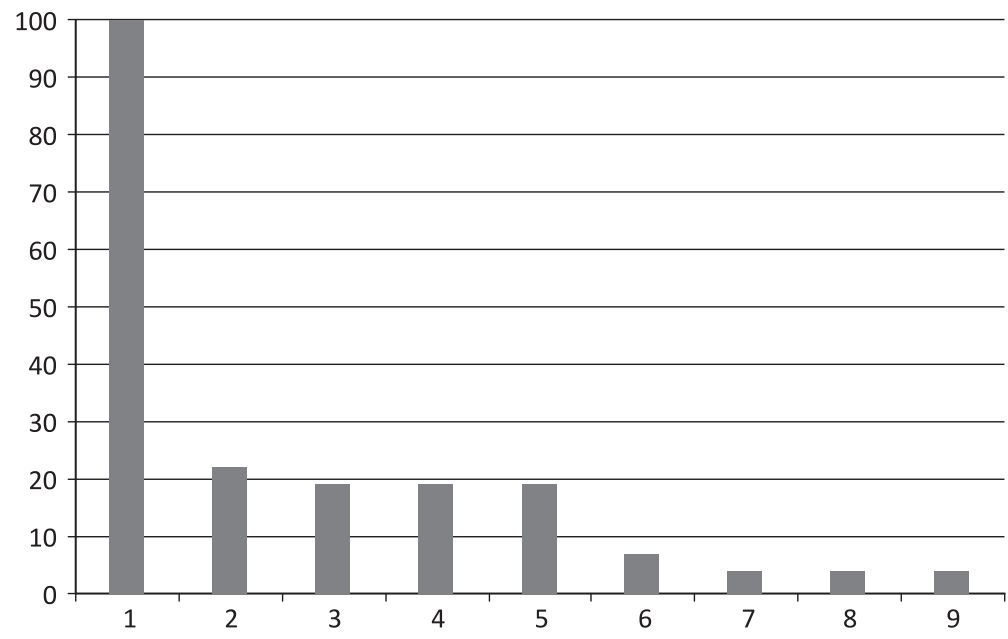

FIGURE 3. Preoperative symptoms in patients with cavum septum pellucidum (digits explained above in the text)

RYCINA 3. Symptomy towarzyszące wypieraniu torbieli przegrody przeźroczystej (objaśnienia cyfr w tekście)

the cistern of the lamina terminalis or the third ventricle via the anterior part of the cyst's bottom wall. However, MRI-CIN examination performed in 4 patients did not visualise the flow of the cerebrospinal fluid via the cyst.

Postoperative investigations in all patients revealed the collapsed side walls of the cyst, with their parallel positioning and enlarged lumen of the anterior horns of the lateral ventricles. In most cases, the holes created by endoscopic fenestration were also visible. Further imaging tests carried out during postoperative monitoring did not reveal any obliteration of the holes created in the cyst walls' fusion or the relapse of the expanding septum pellucidum cyst.

Statistical analysis demonstrated significant differences between pre- and postoperative measurements for the width of the cyst on the axial sections (measurement 1), for the ratio of cyst width to the distance between the anterior horns of the lateral ventricles (parameter $\mathrm{x}$ ), and for the ratio of the transverse dimension of the cyst to the width of the brain on the same section (parameter y).

The increase in postoperative distance between the wall of the cyst and the caput of the caudate nucleus was statistically significant in comparison to the preoperative value. Moreover, a statistically significant difference was found for measurements of the width of the cyst's wall and ventricles on the right side, but not on the left side.

Some data from measurements could not be analysed with statistical tools because of significant differences in the size of the patient group. This resulted from the fact that control imaging tests were carried out in distant medical centres, and findings were unavailable for retrospective analysis. This problem particularly concerns the postoperative analysis of parameters $6,7 a, 7 b, 7 c, 8,9$, and 10 . Nevertheless, findings from investigations carried out on the available population of patients show a tendency for an increase in the value of measurement 7a (the postoperative distance between the chiasma opticum and the rostrum of the corpus callosum). There is also a marked increase in the distance between the dolnej ze zbiornikiem blaszki krańcowej lub z komorą trzecią. Wykonane w 4 przypadkach badania MRI z opcją CIN nie uwidoczniły jednak przepływu PMR przez torbiel.

Badania pooperacyjne we wszystkich przypadkach uwidoczniły zapadnięcie się bocznych ścian torbieli, z ich równoległym ustawieniem względem siebie oraz powiększeniem się światła rogów czołowych komór bocznych. W większości przypadków były także widoczne otwory po endoskopowej fenestracji. W trakcie kolejnych badań obrazowych wykonywanych w okresie obserwacji pooperacyjnej nie stwierdzano przypadków zarastania wykonanych otwarć w ścianach torbieli czy też nawrotu wypierającego charakteru torbieli.

W analizie statystycznej różnica w pomiarach przed leczeniem i po leczeniu operacyjnym okazała się istotna w przypadku szerokości samej torbieli na przekrojach aksjalnych (pomiar 1), w przypadku stosunku szerokości torbieli do rozstawu rogów czołowych komór bocznych (parametr x) oraz w przypadku stosunku wymiaru poprzecznego torbieli do szerokości mózgowia na tym samym przekroju (parametry).

W sposób istotnie statystyczny wzrosła odległość ściany torbieli od głowy jądra ogoniastego po operacji w stosunku do tego parametru przed operacją. Istotna była także różnica w pomiarach szerokości ścian torbieli i komór po stronie prawej. Różnica ta po stronie lewej okazała się nieistotna statystycznie w przypadku przebadanej grupy chorych.

Niektóre pomiary nie mogły być opracowywane narzędziami statystycznymi z uwagi na nieproporcjonalne liczbowo grupy. Powodem tego było wykonywanie kontrolnych badań obrazowych w odległych jednostkach leczniczych, co sprawiało, że były one niedostępne dla oceny retrospektywnej. Dotyczy to szczególnie pooperacyjnej oceny parametru 6, 7a, 7b, 7c, 8, 9, 10. Wyniki badań przeprowadzonych na dostępnej grupie badanych wykazują jednak tendencję do zwiększenie pomiaru 7a - odległości skrzyżowania wzrokowego od dziobu ciała modzelowatego po zabiegu. Zauważalna jest też tendencja do zwiększenia się odległości ciała modzelowatego od sklepienia, co może być pośrednim dowodem na faktyczny ucisk 
corpus callosum and the fornix, which may indirectly prove the compression of the fornix structures by the cyst, which is reduced after surgical intervention, displacing the fornix upwards and lowering the bottom part of the fornicolumns. The width of the corpus callosum was greater in postoperative measurements.

\section{Analysis of treatment and clinical picture in the postoperative period}

All patients were treated surgically (25 with the endoscopic technique and 2 with conventional neurosurgery). Surgical intervention (endoscopic) relieved preoperative headache in $18(72 \%)$ patients. In one case the surgery could not be done because of the collapsing walls of the cyst, which disabled the visual control of the operating field.

Headache recurred in 2 patients who underwent stereotactic puncture. In these cases, reoperation using the endoscopic technique permanently relieved preoperative headache.

For most patients $(17 ; 63 \%)$ the early postoperative period (max. 2 weeks) was free from complications (1). Early postoperative transient ailments were experienced by 10 patients $(37 \%)$ see Figure 4 below. Digits used in the figure are explained in the text below.

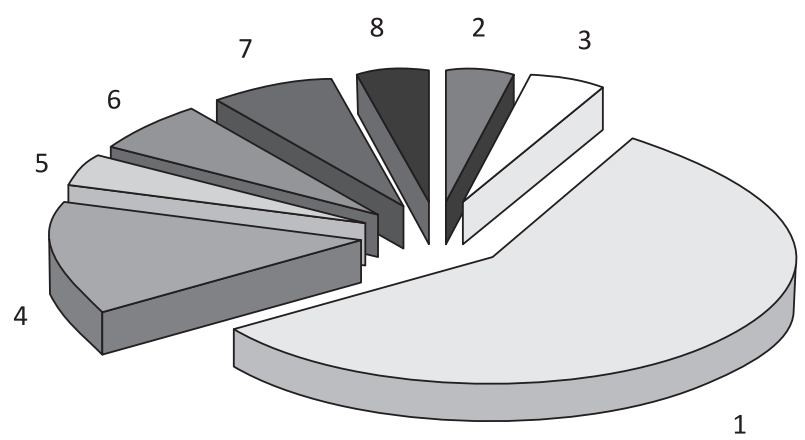

FIGURE 4. Frequency of complications in the early postoperative period (digits explained above in the main text)

RYCINA 4. Częstość powikłań we wczesnym okresie pooperacyjnym (objaśnienia cyfr w tekście powyżej, w nawiasach)

Transient symptoms in the early postoperative period included:

- transient right-side hemiparesis (1 day): 1 patient - 4\% (2),

- transient orthostatic disorders (3 days): 1 patient - 4\% (3),

- transient headache (4 days): 4 patients - 15\% (4),

- transient mental disorders: disorientation to time and place (1 day): 1 patient - 4\% (5),

- loss of recent memory ( 3 days): 2 patients - 7\% (6),

- signs of irritated meninges with neck stiffness (8 days): 1 patient; vomiting, neck stiffness, fever (1 day): 1 patient; 2 patients in total: 7\% (7),

- motor aphasia, disorders of recent memory, right-side hemiparesis, in CT image signs of bleeding into the ventricles: 1 patient - 4\%; in this female patient the fenestration attempt failed - the cyst collapsed under the endoscope and surgery was discontinued (8). torbieli na sktruktury sklepienia, który po interwencji chirurgicznej maleje i powoduje przemieszczenie się sklepienia ku górze oraz obniżenie dolnej części jego słupów. Szerokość ciała modzelowatego była większa na pomiarach po interwencji chirurgicznej.

\section{Omówienie leczenia oraz obrazu klinicznego w okresie pooperacyjnym}

Wszyscy pacjenci przeszli leczenie operacyjne: 25 osób metodą endoskopową, 2 osoby metodą klasyczną. Przyniosło ono ustąpienie przedoperacyjnych dolegliwości bólowych w 18 przypadkach (72\%) operacji wykonanych techniką endoskopową. W 1 przypadku prowadzenie operacji nie było możliwe ze względu na zapadanie się ścian torbieli, co uniemożliwiało wzrokową kontrolę otoczenia operacyjnego.

W 2 przypadkach operowanych na drodze punkcji stereotaktycznej doszło do nawrotu dolegliwości. Reoperacja z użyciem techniki endoskopowej w tych przypadkach przyniosła trwałe ustąpienie przedoperacyjnych dolegliwości bólowych.

Większość chorych, tj. 17 (63\%) osób, przebyło wczesny okres pooperacyjny (do 2 tygodni) bez powikłań (1). W tym okresie 10 (37\%) osób doświadczyło dolegliwości przejściowych, co przedstawiono na rycinie 4.

Do dolegliwości przejściowych we wczesnym okresie pooperacyjnym należały:

- przejściowy niedowład prawostronny (1 doba): 1 osoba$4 \%(2)$,

- przejściowe zaburzenia ortostatyczne (3 doby): 1 osoba$4 \%$ (3),

- przejściowe bóle głowy (4 doby): 4 osoby - 15\% (4),

- przejściowe zaburzenia umysłowe: orientacji allopsychicznej (1 doba): 1 osoba - 4\% (5),

- ubytki pamięci świeżej (3 doby): 2 osoby - 7\% (6),

- cechy podrażnienia opon mózgowo-rdzeniowych wraz ze sztywnością karku (8 dób): 1 osoba; wymioty, sztywność karku, gorączka (1 doba): 1 osoba; razem 2 osoby - 7\% (7),

- afazja motoryczna, zaburzenia pamięci świeżej, niedowład połowiczy prawostronny, w TK cechy krwawienia do komór: 1 osoba - 4\%; u tej pacjentki próba fenestracji nie powiodła się - torbiel zapadnięta na endoskopie, krwawienie - zaniechano kontynuacji (8).

W 2 (7\%) przypadkach pojawił się nawrót dolegliwości w okresie późnym (>2 tygodni) po zabiegu. Bóle głowy w jednym - po upływie 3 tygodni od zabiegu, w drugim napad padaczkowy - 2 miesiące po operacji. Jeden z pacjentów prezentował dolegliwości we wczesnym okresie pooperacyjnym, drugi nie. Chorzy zostali poddani reoperacji metodą endoskopową, po której nie stwierdzono powracających dolegliwości.

\section{DYSKUSJA}

Symptomatologia torbieli przegrody przeźroczystej u pacjentów leczonych chirurgicznie

Jak wynika z badań własnych, chorzy z WTPP cierpieli z powodu: bólów głowy, zawrotów głowy, nudności i wymiotów, 
In $2(7 \%)$ patients symptoms recurred in the late postoperative period (over 2 weeks). One patient had headaches 3 weeks postoperatively, and another patient had an epileptic seizure 2 months postoperatively. One of 3 patients had symptoms in the early postoperative period but not the other. The patients were reoperated on endoscopically and symptoms did not recur further.

\section{DISCUSSION}

\section{Symptomatology of the septum pellucidum cyst in surgically treated patients}

The carried out study identified the following symptoms in patients with ESPC: headache, dizziness, nausea and vomiting, advanced nervous function disorders, epileptic seizures, visual defects, psychiatric disorders, tinnitus, and nocturia (ordered in decreasing frequency).

The clinical picture of patients presented here is similar to that described in the literature, although specific symptoms are reported by other authors with variable frequency. This may be due to the fact that most reports concern smaller populations of patients and present descriptions of pathological SP coexisting with the cysts. Most of the available reports are case studies, and the group of 27 patients analysed here is one of the largest $[7,12,18,34,35,36,37,38,39$, $40,41,42,43,44]$.

In 1996 Lancon et al. reported the case of a patient with septum pellucidum cyst (SPC) who had headache, loss of consciousness, and behaviour changes (hyperactivity and missing school). The symptoms were resolved after surgical treatment.

The detailed pathomechanism of CSP transformation into ESPC is not fully understood [45]. Nevertheless, Lancon et al. indicated four major mechanisms that may explain the nature of the expanding cysts [46].

These mechanisms include: obstructed flow of the cerebrospinal fluid via the foramen of Monroe, compression of vascular structures, compression of the hypothalamic-septal triangle, and compression of the optic structures.

The obstructed flow of CSF through the foramen of Monroe has been reported in many studies (e.g. Ronsin et al., Amin, and other researchers [28, 34, 47].

Another term used in the literature is the "ballvalve phenomenon" [2, 3, 48].

According to some authors, the compression of the septum pellucidum alone cannot produce pain [25]. This theory has been argued by Wester et al., who claimed that the irritation of this area is the factor responsible for pain. They also found that at the moment of the stereotactic cyst puncture in awake neurosurgery patients reported the same type of pain that they had in the preoperative period [49]. Wester et al. also claim that pain does not result from the general increase in ICP, but the stretching of the adjacent structures sensitive to pain [50].

Regardless of its pathogenesis, headache in the course of ESPC in patients assessed preoperatively in this study was recurrent and increased in severity over time. Therefore, it is zaburzeń wyższych czynności nerwowych, napadów padaczkowych, zaburzeń widzenia, zaburzeń zdrowia psychicznego, szumów w uszach, moczenia nocnego (w kolejności od najczęściej do najrzadziej występujących objawów).

Obraz kliniczny chorych tu przedstawiony jest podobny do zespołu opisywanego w literaturze tematu, jakkolwiek poszczególne objawy podawane są różnie często w doniesieniach autorów. Może to wynikać z faktu publikowania materiału opartego najczęściej na mniej licznych grupach i opisywania patologii PP współistniejących z torbielą. Zwykle są to opisy kazuistyczne, a grupa 27 chorych analizowanych w niniejszej pracy jest jedną z najliczniejszych $[7,12,18,34,35$, $36,37,38,39,40,41,42,43,44]$.

Lancon $i$ wsp. opisali w 1996 r. przypadek chorego z TPP z bólami głowy, utratą przytomności, zmianą zachowania, tj. nadaktywnością oraz opuszczaniem obowiązków szkolnych. Objawy u przedstawianego przez nich pacjenta ustąpiły po leczeniu chirurgicznym.

Dokładny patomechanizm transformacji TPP w WTPP nie został do tej pory zbadany [45]. Lancon i wsp. wymieniają natomiast 4 zasadnicze mechanizmy, które zdają się tłumaczyć charakter torbieli wypierających [46]. Są to: zablokowanie przepływu PMR przez otwór międzykomorowy, ucisk na struktury naczyniowe, ucisk na struktury trójkąta podwzgórzowo-przegrodowego oraz ucisk na struktury wzrokowe.

Zablokowanie przepływu przez otwór Monroe wspominane jest w wielu pracach. Zjawisko to opisywali już wcześniej Ronsin i wsp., Amin, a także inni autorzy [28, 34, 47]. W piśmiennictwie tematu pojawia się też pojęcie tzw. ballvalve phenomen - zjawiska zastawki [3, 12, 48].

Według niektórych autorów ucisk na przegrodę przeźroczystą samą w sobie nie może być źródłem bólu [25]. Polemizują z tym Wester $i$ wsp., uważając, że to właśnie drażnienie tej okolicy daje dolegliwości bólowe. Zaobserwowali oni w momencie stereotaktycznego nakłucia torbieli podczas operacji wybudzeniowych, iż pacjenci zgłaszali ten sam rodzaj bólu, jak ten, który towarzyszył im w okresie przedoperacyjnym [49]. Autorzy ci twierdzą też, że ból nie jest wynikiem ogólnego wzrostu ICP, a rozciąganiem struktur wrażliwych na ból w sąsiedztwie [50].

Niezależnie od jego patogenezy, ból w przebiegu WTPP w badaniach własnych u pacjentów przed operacją miał charakter nawracający i nasilający się z biegiem czasu. Zasadnym zatem wydaje się przyjęcie, iż podłożem jego powstawania może być powolne napełnianie się torbieli. Napełnianie to dokonuje się głównie za pomocą mechanizmu zastawkowego. Mechanizm ten został zaobserwowany in vivo przez L. Sagana podczas zabiegu operacyjnego z użyciem endoskopu. Spostrzeżenie to, nieopisane w piśmiennictwie, pozwala potwierdzić hipotezę o patomechanizmie zastawkowym powiększania TPP. Może być rozważane również jako potencjalna przyczyna patologii wzrostu torbieli pajęczynówki.

Po zabiegu operacyjnym istotnie malały wymiary poprzeczne torbieli i ustępowały dolegliwości. Nie zmieniała się natomiast szerokość samych komór. Stąd można wnioskować, iż jednym z czynników odpowiedzialnych za pojawienie 
reasonable to assume that the slow filling of the cyst is the process underlying the onset of headache. The cyst filling occurs mainly due to the valve mechanism, originally observed in vivo by L. Sagan during an endoscopic surgery. This unpublished finding supports the hypothesis on the involvement of the valve mechanism in the expansion of SPC. It may also be considered as a potential pathological factor responsible for the growth of arachnoid cysts.

Surgical treatment resulted in a significant decrease in the transverse dimensions of the cyst and relief of symptoms, but had no effect on the width of the ventricles. Therefore, it can be concluded that changes in the cyst volume, not in the size of ventricles, are a factor responsible for the onset of symptoms.

Other mechanisms of cyst expansion have also been described. According to Lancon et al., CSF may be secreted by the cells lining the cyst from the inside, previously identified as migrating ependymal cells [16]. This hypothesis was challenged by Richards et al. [51].

Morphological and secretory hypotheses were also put forward by other researchers. Liss and Mervis claimed that the cyst is lined with unspecialised astrocytes which in adults become similar to ependymal cells lining the ventricles. They also suggested that the cells evolve with age or may transform into other types of cells, causing cyst expansion [19]. Oteruelo et al. suggested the hypothesis of a passive passage of CSF via septal leaves based on a pressure gradient, and septal capillaries and veins may be involved in fluid resorption. This hypothesis was supported by Sencera et al., who found that small septal vessels enable the drainage of the cava septi pellucidi and Vergae [3].

To date, there has been no evidence supporting the validity of the valve mechanism. Intraoperative findings made during the gathering of material for this dissertation (endoscopic neurosurgeries) provided evidence for this mechanism. In view of this, the hypothetic mechanisms reported by other authors should be considered as accompanying and coexisting the valve mechanism. In conclusion, cyst expansion may result from several mechanisms, but the valve mechanism is the only one observed in vivo.

\section{Compression of vascular structures}

Neciga et al. reported cases of the expanding septum pellucidum cyst compressing the venous structures of the brain [52]. However, Dandy was the first to describe the dilation of superficial cortical veins of the left ventricle joining the enlarged vein of Roland. Small vessels within the cyst were unchanged on inspection, so Dandy concluded, as quoted by Lancon et al. that the arteriovenous malformation was not the cause of vein dilation. In later studies Lancon demonstrated that this evidenced the indirect compression of deep collateral veins by the cyst $[16,46]$. Aoki, on the other hand, concluded that the vein compression may produce the symptoms of ESPC [53].

The analysis of preoperative and postoperative radiographic images from patients revealed significant differences in the distance between the SPC lumen and the caudal nucleus (the się symptomów są zmiany objętości torbieli, nie zaś zmiany w wielkościach komór.

W piśmiennictwie opisywane są inne mechanizmy powiększania się torbieli. Według Lancona i wsp. możliwe jest wydzielanie PMR przez komórki wyścielające torbiel od wewnątrz, które postrzegano jako migrujące ependymocyty [16]. Richards i wsp. podważali tę hipotezę [51].

Morfologicznie wydzielnicze hipotezy przedstawiane były też przez innych autorów. Liss i Mervis uważają, że torbiel wyścielona jest niewyspecjalizowanymi astrocytami, które u dorosłych stają się podobne do komórek ependymalnych wyścielających komory. Sugerowali oni przy tym ewolucję związaną z wiekiem lub możliwość przemiany jednych komórek w drugie powodującą powiększanie się torbieli [19]. Oteruelo i wsp. natomiast zaproponował hipotezę pasażu pasywnego PMR przez blaszki przegrody za pomocą gradientu ciśnieniowego. Resorpcja płynu miałaby się odbywać przez przegrodowe kapilary i żyły. Hipoteza ta została poparta przez Sencera i wsp., którzy stwierdzali, że drenaż TPP i jamy Vergi możliwy jest za pomocą małych naczyń przegrodowych [3].

Do tej pory nie udało się udowodnić mechanizmu zastawkowego. Obserwacje śródoperacyjne poczynione podczas zbierania materiału do niniejszej pracy (zabiegi z wykorzystaniem endoskopu) pozwoliły uznać go za jedyny udowodniony. Należy natomiast uznać pozostałe, przytaczane jako hipotetyczne przez innych autorów, za mające znaczenie dodatkowe i współistniejące z mechanizmem zastawkowym. Powiększanie torbieli może więc następować wskutek kilku mechanizmów, z których jedynie zastawkowy został zaobserwowany in vivo.

\section{Ucisk na struktury naczyniowe}

Neciga i wsp. opisują przypadki, w których nacisk powiększającej się torbieli przegrody przeźroczystej miał wpływ na układ żylny naczyń mózgowia [52]. Dandy jednak jako pierwszy opisał poszerzanie się powierzchownych żył korowych prawej komory uchodzących do powiększonej żyły Rolanda. Małe naczynia w obrębie samej torbieli w jego obserwacji nie były zmienione, stąd Dandy wnioskował, jak przytacza Lancon $i$ wsp., że to nie tętniczo-żylna malformacja jest powodem poszerzenia żył. Jednak dopiero później Lancon wykazał, iż był to dowód na pośredni ucisk przez torbiel żył głębokich, które formowały w ten sposób krążenie oboczne [16, 46]. Aoki natomiast uznał, że uciśnięte żyły głębokie mogą prowadzić do pojawienia się objawów WTPP [53].

Analiza obrazów radiologicznych chorych przed zabiegiem i po zabiegu operacyjnym wykazuje znaczne różnice odległości światła TPP od jądra ogoniastego. Przed zabiegiem opróżnienia torbieli odległość ta była mniejsza niż po odbarczeniu. Pozwala to przypuszczać, że część objawów towarzyszących chorym z TPP może być wywołana przez ucisk bądź wpływ naczynioruchowy na sąsiadujące struktury, w tym jądra podkorowe.

Ucisk na struktury tzw. trójkąta podwzgórzowo-przegrodowego mógłby natomiast tłumaczyć zaburzenia wyższych czynności nerwowych manifestowane w badanych przypadkach.

Podobnie inni autorzy opisują zmiany zachowania, czynności układu autonomicznego, labilność emocjonalną, zaburzenia 
distance increased after surgical decompression). This allows for the conclusion that some symptoms in patients with SPC may be caused either by compression or vasomotor effect on adjacent structures, including the subcortical nuclei.

Compression of the hypothalamic-septal triangle could be a factor explaining advanced nervous function disorders identified in the analysed patients.

Other authors also reported behaviour changes, autonomic dysfunction, emotional lability, and advanced nervous function disorders in patients with SPC [3, 5, 7, 16, 25, 39, 46, 54]. Symptoms reported include impaired memory, retardation, hyperactivity, impaired concentration, sleep rhythm disorders, night screams, urinary incontinence, hyperthermia, anorexia and weight loss.

In my study psychiatric disorders were diagnosed in 2 patients. They had the form of psychotic disorders (1) and obsessive-compulsive disorder (1), and seem to be in line with reports by other authors. It is known from the literature that ESPC can coexist with a wide spectrum of psychiatric disorders $[9,12,18,21,30,34]$.

In the age group of 21-40 years SPC is more frequent in patients with schizophrenia. In patients aged $41-60$ years it is associated with alcoholism, and in patients older than 61 years it coexists with a history of head injury [30]. It has been reported that SPC coexisting with schizophrenia is a poor prognostic factor of mental illness [30]. This may confirm the role of SPC in the organic dysfunction of adjacent structures. In many cases SPC is accidentally identified during the imaging of patients with bipolar disorder [30]. Paranoid syndrome, psychosomatic syndromes, and non-specific psychotic disorders concomitant with SPC have also been reported [9, 13].

However, some symptoms occurring in patients with SPC may not be related to SPC but the generalised dysgenesis of CNS. This may explain why the symptoms do not subside after surgical treatment, as proven in this study. This problem is an important aspect of prognosis and postoperative recovery, and should be discussed with the patient prior to surgery, to clarify the patient's expectations.

There is a consensus among the authors that the presence of SPC may prove a dysfunction responsible for non-specific psychiatric disorders produced by a direct or indirect effect of local structures on blood circulation, particularly in veins [9].

In this study 2 patients had visual defects. Visual impairment in patients with SPC was also pointed out by Lancon et al., Kansu and Bertan [16, 18, 37, 39, 50, 55], who reported cases of bilateral temporal hemianopsia and optic disc oedema $[5,55]$. The analysis of radiographic images from patients with SPC carried out in this study supports findings by these researchers. The analysis of material presented here revealed changes in the distance between the corpus callosum and the optic chiasm measured on sagittal sections before and after surgery. The difference, most likely resulting from the reduced size of the cyst in the transverse and the sagittal projection, can be indicative of the preoperative direct compression of optic structures by an expanding cyst and the onset of visual symptoms. wyższych czynności nerwowych u badanych chorych z TPP [3, $5,7,16,25,39,46,54]$. Opisywane przy tym są m.in. zaburzenia pamięci, opóźnienie rozwoju, nadaktywność, pogorszenie koncentracji, zaburzenia rytmu snu, krzyki nocne, nietrzymanie moczu, hipertermia, anoreksja i utrata wagi.

Zaburzenia psychiczne występowały u 2 chorych w analizowanym materiale własnym. Przybrały one postać zaburzeń psychotycznych w jednym oraz nerwicy natręctw w drugim przypadku i zdają się potwierdzać opisy innych autorów. W piśmiennictwie podawane jest współwystępowanie WTPP z zaburzeniami zdrowia psychicznego przyjmującymi szeroką gamę $[9,12,18,21,30]$.

W przedziale wieku 21-40 lat TPP występuje częściej u osób chorych na schizofrenię. W wieku 41-60 lat u alkoholików, $\mathrm{w}$ wieku $>61$ lat u chorych po urazach głowy [30]. Jak donoszą autorzy innych prac, w przypadku gdy TPP występuje razem ze schizofrenią, obserwowane jest gorsze rokowanie choroby psychicznej [30]. Może to potwierdzać rolę organicznie warunkowanej dysfunkcji swych okolic przez TPP. Jakże często, gdy zaburzenia psychiczne towarzyszą uszkodzeniom organicznym, TPP znajdowano przypadkowo w badaniach obrazowych osób cierpiących na chorobę dwubiegunową [30]. Znany jest również zespół paranoidalny, zespoły psychoorganiczne, nieswoiste zaburzenia psychotyczne jako zaburzenia psychotyczne współistniejące z TPP [9, 13].

Zatem niektóre objawy występujące u chorych z TPP mogą nie być związane z nią, lecz z ogólną dysgenezą CUN. Tłumaczyć to może fakt, iż nie ustąpią po leczeniu operacyjnym, co zostało udowodnione w niniejszym materiale. Zagadnienie to jest ważnym aspektem $\mathrm{w}$ rokowaniu i przebiegu pooperacyjnym, który powinien być omówiony z chorym przed operacją celem weryfikacji jego oczekiwań.

Istnieje zgoda wśród autorów, że obecność TPP może dowodzić dysfunkcji powodującej występowanie nieswoistych zaburzeń psychicznych poprzez oddziaływanie na struktury tej okolicy bezpośrednio oraz pośrednio przez zaburzenia krążenia, zwłaszcza żylnego [9].

Dwoje pacjentów spośród wszystkich badanych miało ubytki w zakresie funkcji wzroku. Na zaburzenie widzenia u chorych z TPP zwracają uwagę również Lancon i wsp. oraz Kansu i Bertan [16, 18, 37, 39, 50, 55]. Autorzy ci opisują w tych przypadkach obustronną skroniową hemianopsję i obrzęk tarczy nerwu wzrokowego [5, 55]. Przeprowadzona w pracy analiza zdjęć radiologicznych chorych z TPP potwierdza spostrzeżenia tych badaczy. Na podstawie wyników uzyskanych w prezentowanym materiale wykazano bowiem zmianę odległości ciała modzelowatego od skrzyżowania wzrokowego mierzoną na przekrojach strzałkowych przed operacją i po operacji. Różnica ta, wynikająca najprawdopodobniej ze zmniejszenia rozmiarów torbieli, nie tylko w wymiarze poprzecznym, ale także strzałkowym, wskazywałaby na uprzedni, bezpośredni ucisk struktur wzrokowych przez powiększającą się torbiel, co wywołuje powstawanie objawów wzrokowych.

Zespół przegrody przeźroczystej omawiany przez Silberta i wsp. jako odpowiadający zespołowi WTPP składa się z zaburzeń osobowości, ataksji, zaburzeń mowy, napadów 
The cavum septum pellucidum syndrome reported by Silbert et al., as corresponding with ESPC, is manifested by personality disorders, ataxia, speech disorders, epileptic seizures and bilateral pyramidal signs [21]. However, these disorders were diagnosed by examining patients at a time when diagnosis and its verification could be done using invasive pneumoencephalography or in post-mortem examination.

The findings presented here, made based on images from MRI, CT and intraoperative assessment, help to clarify the clinical picture of ESPC. It is justified to classify headache, dizziness, nausea and vomiting, advance nervous function disorders, epileptic seizures and visual defects as the most frequent clinical symptoms of ESPC syndrome.

\section{Natural history of the expanding septum pellucidum cyst}

The natural history of expanding SPC is determined by the interaction of forces acting inside the cyst (increase of volume) and those acting from the inside (resistance of adjacent tissues).

Shaw et al. concluded that increasing thickness of the cyst wall resulting from injury, inflammation, postoperative lesions and decrease in intraventricular pressure is a major factor determining cyst expansion [25].

Other authors reported cases of spontaneous resolution of a cyst as a result of rupture to the cyst wall caused by the pressure of CSF accumulating inside it $[25,56]$.

In patients with coexisting hydrocephalus, intraventricular pressure is so high that it may reduce the thickness of the cyst wall [25]. Indeed, in patients examined in this study the thickness of the cyst wall was significantly lower before decompression than after surgery, which confirms this mechanism.

Shaw et al. indicated that as long as the expanding cyst does not obstruct the flow of CSF through the interventricular foramina it remains asymptomatic and non-pathological [25]. Closer monitoring of patients with accidentally diagnosed SPC for the onset of symptoms seems reasonable. It may help in differential diagnosis of symptomatic and asymptomatic cases.

The balance between pressure gradients on both sides of the cyst wall is disturbed when the cyst obstructs the foramen of Monroe or the lumen of a lateral ventricle, leading to recurrent difficulties in the flow of CSF in this area [25,40]. As a result, pressure in the lateral ventricles increases and the cyst wall is displaced from the foramen of Monroe.

Amin, quoted by Silbert et al., concluded, however, that in ESPC the cyst side walls become stretched and enlarged in the sagittal plane, which results in the caudal displacement of the fornix, pressure on the thalamus, and obstructed flow via the intraventricular foramina. The foramina are additionally obstructed by inner cerebral veins, and a further increase in the high intracranial pressure occurs [21].

It can be speculated based on these findings that the further expanding cyst increases its volume caudally, thus moving away from the foramina of Monroe and decompressing them. In patients this process is manifested as a relief between the padaczkowych oraz obustronnych objawów piramidowych [21]. Zaburzenia te stwierdzano jednak, badając pacjentów w czasie, w którym możliwa była diagnoza i weryfikacja rozpoznania jedynie za pomocą uraźliwej pneumoencefalografii oraz w badaniu pośmiertnym.

Prezentowane własne obserwacje na podstawie obrazowania MRI, TK i oceny śródoperacyjnej pozwalają uściślić obraz kliniczny WTPP. Istnieją podstawy, by do objawów klinicznych zespołu WTPP zaliczyć: bóle głowy, zawroty głowy, nudności i wymioty, zaburzenia wyższych czynności nerwowych, napady padaczkowe oraz zaburzenia widzenia jako najczęściej występujące.

\section{Historia naturalna rozwoju torbieli przegrody przeźroczystej}

Naturalna historia TPP warunkowana jest zmaganiem się sił działających od wewnątrz torbieli (powiększanie jej objętości) i działających od zewnątrz (opór sąsiadujących tkanek).

Shaw i Alvord stwierdzili, że zwiększanie grubości ścian torbieli w wyniku urazów, stanów zapalnych, zmian pooperacyjnych oraz obniżanie ciśnienia wewnątrzkomorowego to główne czynniki prowadzące do rozwoju torbieli [25].

W piśmiennictwie opisywane są przypadki tzw. spontanicznych regresji, tzn. pękania ścian torbieli z naporu gromadzącego się wewnątrz PMR [25, 56].

W przypadkach współistniejącego wodogłowia ciśnienie wewnątrzkomorowe jest tak duże, że istnieją warunki do zmniejszenia grubości ścian torbieli [25]. U pacjentów przebadanych w pracy własnej grubości ścian torbieli były faktycznie istotnie mniejsze przed odbarczeniem niż po, co potwierdza ten mechanizm.

Dopóki powiększająca się torbiel nie utrudnia przepływu PMR przez otwory międzykomorowe, pozostaje asymptomatyczna i - jak uznają Shaw i Alvord - nie jest patologią [25]. Bliższa obserwacja chorych w przypadkach incydentalnie rozpoznanej TPP w aspekcie pojawiających się dolegliwości wydaje się zasadna. Mogłoby to pomóc w różnicowaniu przypadków, które mogą stać się symptomatyczne i przypadków pozostających bezjobjawowymi.

Równowaga między ciśnieniami po obu stronach ściany torbieli znika, gdy torbiel zwęża otwór Monroe lub światło komory bocznej, co prowadzi do nawracającego utrudnienia przepływu PMR w tym obszarze $[25,40]$. To z kolei powoduje wzrost ciśnienia w komorach bocznych i odepchnięcie ściany torbieli od otworu Monroe.

Amin, cytowany przez Silberta i wsp., uważa natomiast, że w przypadku WTPP ich ściany boczne napinają się oraz powiększają w płaszczyźnie strzałkowej, co powoduje przemieszczenie sklepienia w kierunku doogonowym, wywołując ucisk na wzgórze i utrudnienie przepływu przez otwory międzykomorowe. Te dodatkowo ograniczane są przez wewnętrzne żyły mózgowe, nasilające podniesione już ciśnienie wewnątrzczaszkowe [21].

Na podstawie powyższych obserwacji wydaje się możliwe, iż rosnąca torbiel w dalszym stadium powiększa swoją objętość w kierunku doogonowym, przez co w konsekwencji odsuwa 
subsequent episodes of headache. After some time the cyst, with walls stretched by the previous expanding process, is refilled. Similar recurrent symptoms were observed in the population of patients analysed in this study.

Measurements of cysts and their surrounding areas additionally support both interpretations of causative factors and the mechanism of the natural history of ESPC.

\section{Risk factors of septum pellucidum syndrome}

Some researchers link the transformation of SPC into ESPC with specific risk factors. Most frequently, these are head injuries, increased intracranial pressure, and a history of surgical interventions in the cyst area [50,53]. This is confirmed by statistically higher incidence of ESPC reported in professional boxers $[39,57,58]$.

Of all patients analysed in this study only one had a history of head injury accompanied with loss of consciousness in childhood.

\section{Diagnosis of the septum pellucidum cyst and indications for surgical treatment}

Shaw and Alvord, Meng et al. noted that some reports describe cases of ESPC even if the cyst was not large enough to compress the adjacent structures or obstruct the flow of CSF [7, 25]. Shaw and Alvord also presents results from post mortem examinations, where large SPCs were identified frequently in asymptomatic patients [25].

Findings from this study support suggestions that the width/ size of the cyst is not a decisive factor for the dynamics and severity of clinical symptoms. In some cases, similar symptoms were caused by smaller cysts, while in other cases by cysts larger in the sagittal plane.

Sarwar concluded that most reports define SPC as a min. $10 \mathrm{~mm}$-wide space with rounded walls, identified by CT or MRI [59].

This suggest that the diagnosis of a symptomatic septum pellucidum cyst should be made in cases meeting radiographic criteria based on axial sections and presenting with clinical symptoms of ESPC syndrome.

At the same time this indicates the need for surgical decompression of the cyst after differential diagnosis has been done. Other authors also support this approach [7, 37, 48, 49].

Nevertheless, there are studies encouraging watchful waiting, even in patients with ESPC, if the cyst does not cause hydrocephalus or a progressive neurological dysfunction. Hong et al. give the relevant example of a 38 years woman who had a spontaneous resolution of a cyst [56].

However, the low risk of complications, almost immediate relief of symptoms after decompressive surgery and the low percentage of recurrence offered by the surgical treatment of ESPC sufficiently justify decisions on surgical intervention.

\section{Surgical treatment of patients with expanding septum pellucidum cyst}

Until 2005 there were no scientific reports specifying precise standards for the management of ESPC [37]. się od otworów Monroe i odbarcza je. U chorego manifestuje się to jako uczucie ulgi po kolejnej fali bólu. Po upływie czasu dochodzi do ponownego napełniania się torbieli, której ściany rozciągnięte są już wcześniej wypierającym procesem. Podobny schemat nawracających objawów można było zaobserwować, analizując grupę badaną w pracy własnej.

Przeprowadzone pomiary torbieli i okolic pozwalają dodatkowo przyjąć za słuszne obie interpretacje przyczyn i mechanizmu naturalnej historii TPP.

\section{Czynniki ryzyka wystąpienia zespołu przegrody przeźroczystej}

Niektórzy autorzy zwracają uwagę na obecność czynnika, który miałby powodować przejście TPP w WTPP. Najczęściej wymieniane są tu urazy głowy, wzrost ciśnienia wewnątrzczaszkowego oraz wcześniejsze ingerencje chirurgiczne w obrębie torbieli $[50,53]$. Potwierdzają to statystyki mówiące o wyższym procencie zachorowań na WTPP wśród bokserów zawodowych $[39,57,58]$.

Spośród analizowanych w materiale własnym przypadków tylko w jednym stwierdzono w wywiadzie uraz głowy z utratą świadomości w dzieciństwie.

\section{Rozpoznanie torbieli przegrody przeźroczystej, wskazania do leczenia operacyjnego}

Również Meng i wsp. oraz Shaw i Alvord zauważyli, że w niektórych doniesieniach opisywane są przypadki WTPP, nawet jeśli rozmiary torbieli nie były na tyle duże, by ucisnąć przyległe struktury lub blokować przepływ PMR [7, 25]. Shaw i Alvord podają przy tym wyniki badań autopsyjnych, w których często wykrywano TPP o dużych rozmiarach, które jednak nie były źródłem objawów za życia pacjentów [25].

Zebrane wyniki w pracy własnej potwierdzają spostrzeżenia, iż szerokość torbieli, a więc jej rozmiar, nie ma decydującego wpływu na dynamikę i intensywność dolegliwości. W niektórych przypadkach mniejszych rozmiarów torbiele wywoływały podobne dolegliwości, jak w innych te o większych wymiarach poprzecznych.

Sarwar stwierdza, że w większości doniesień za TPP uznaje się przestrzeń stwierdzaną w TK lub MRI o szerokości minimum 10 mm, o „zaokrąglonych” ścianach [59]. Wydaje się zatem, że rozpoznanie objawowej torbieli przegrody przeźroczystej powinno być postawione w przypadkach spełniających kryterium radiologiczne, w oparciu o przekroje aksjalne oraz prezentującego symptomy kliniczne zespołu WTPP. Równocześnie jest to wskazanie do odbarczenia torbieli metodą operacyjną po przeprowadzeniu diagnostyki różnicowej. Potwierdzają to również prace innych autorów [7, 37, 48, 49].

Istnieją opracowania popierające metodę czujnego wyczekiwania w odniesieniu nawet do WTPP, ale dotyczy to tych, które nie wywołują wodogłowia czy postępującego upośledzenia funkcji neurologicznych. Hong i wsp. popierają to obserwacją przypadku 38-letniej kobiety, u której wystąpiła spontaniczna regresja [56]. Biorąc jednak pod uwagę niskie ryzyko powikłań, prawie natychmiastowe ustąpienie dolegliwości po zabiegu odbarczającym i niski procent nawrotów w przypadku 
Since 1931, when Dandy first described the surgical treatment of ESPC, various fenestration techniques have been attempted [5, 37, 48]. Initially, a classical transcortical fenestration was used. Next, ESPC was treated with stereotactic puncture and cystoventricular shunting, as well as a valve with the peritoneal catheter. Recently, standard endoscopic neurosurgery or navigator system-assisted endoscopy have become more popular.

Today, endoscopic fenestration of SPC is considered the method of choice due to its low number of complications and the high efficiency of the procedure $[7,34,37,40,48,60]$.

The advantages of endoscpic fenestration include short operative time (in this study less than 1.5 hours), low invasiveness, and the ability to sample material for histopathological examination [60].

One of the major benefits of this technique is the ability of direct in vivo observation of the ventricular and cyst lumen, the foramen of Monroe, before and after fenestration. In this study, such observations provided key evidence supporting the hypothesis on the valve mechanism being involved in cyst expansion. All these benefits were also noted by other researchers $[37,60]$.

Fenestration via posterior access has also been reported, and Gangemi et al. considered it more beneficial due to wider transverse dimensions of the lateral ventricles in the midline part [6]. However, most authors prefer frontal access $[7,40]$. Bilateral access surgeries have also been attempted, but the same authors recommend unilateral access as sufficient [36].

Meng et al. prefer a rigid endoscope [7], which ensures better illumination and a high resolution image. Unfortunately, the rigid endoscope offers a limited field of view due to its single trajectory [40].

The navigator system in endoscopic surgery is useful when the procedure is precisely planned. Some authors claim that its efficiency during surgery is limited because changes in the volume of CSF may displace intracranial structures and bias the estimates of previous penetration [5]. Despite that, the navigator system prevents the penetration of an endoscope in the functionally important areas, thus eliminating the risk of complications such as those found in one patient analysed in this study $[5,7,18]$.

Fenestration of the cyst wall should be performed in an avascular area. Oertel et al. provide detailed instructions, and recommend an area about 5-10 mm posteriorily from the foramen of Monroe, half way between the corpus callosum and the fornix. This area is usually free from septal veins, and complications can be avoided. This area is also convenient for the insertion of an endoscope in order to assess the internal walls of the cyst and carry out fenestration of the opposite side [18]. In patients treated at the Department of Neurosurgery PMU operators fenestrated an area 5-10 mm anteriorily from the foramen of Monroe. Medical records show that this was an area free from veins, and more convenient because it allowed for the observation of all critical structures (the foramen of Monroe, the ventricular wall, the caudal nucleus). operacyjnego leczenia WTPP, decyzja o interwencji chirurgicznej była uzasadniona.

\section{Leczenie chirurgiczne pacjentów z wypierającą torbielą przegrody przeźroczystej}

W piśmiennictwie naukowym do 2005 r. nie ma jasno określonych standardów dotyczących postępowania w przypadku WTPP [37].

Od 1931 r., kiedy Dandy po raz pierwszy opisał chirurgiczną metodę leczenia WTPP, próbowano fenestrować ją różnymi sposobami [5, 37, 48]. Znana od początku była metoda klasyczna poprzez dostęp transkortykalny. Później leczono TPP za pomocą nakłucia stereotaktycznego, przy użyciu przecieku torbielowo-komorowego, a także zastawki z odprowadzeniem do otrzewnej. W ostatnim okresie występuje tendencja do stosowania endoskopii lub endoskopii ze wspomaganiem neuronawigacją.

Metoda fenestracji TPP z użyciem endoskopu jest dziś uznawana za metodę z wyboru z uwagi na małą liczbę powikłań i dużą efektywność zabiegu [7, 34, 37, 40, 48, 60]. Jako zalety zabiegu z wspomaganiem endoskopowym należy wymienić: krótki czas zabiegu (w materiale własnym krótszy niż 1,5 godz.), mała inwazyjność, możliwość pobrania materiału histopatologicznego [60].

Jedną z ważniejszych zalet tej metody jest możliwość bezpośredniego wglądu in vivo w światło komór i torbieli, otwór Monroe przed fenestracją oraz obserwacja skutków tej fenestracji. W pracy własnej dostarczyło to kluczowego dowodu na poparcie hipotezy mechanizmu zastawkowego powiększającego torbiel. Zalety te dostrzegane są również przez innych badaczy [37, 60].

W piśmiennictwie są wzmianki o dostępie tylnym, który przez Gangemi i wsp. uznawany jest za korzystniejszy z uwagi na szerszy wymiar poprzeczny komór bocznych w części środkowej [6]. Jednak większość autorów preferuje dostęp czołowy $[7,40]$. Próbowano również dostępów obustronnych bocznych, lecz ci sami autorzy zalecają dojście jednostronne jako wystarczające [34].

Meng i wsp. preferują endoskop sztywny [7], który zapewnia lepsze oświetlenie i wysoką rozdzielczość obrazu. Wadą sztywnego endoskopu jest natomiast ograniczenie pola operacyjnego z uwagi na pojedynczą trajektorię [40].

Nawigacja w zabiegach endoskopowych ma swoje zastosowanie przy dokładnym planowaniu zabiegu. Według niektórych autorów jej efektywność podczas operacji nie jest wysoka, gdyż zmiany w objętości PMR mogą powodować przemieszczanie się struktur wewnątrzczaszkowych, zakłócając wcześniejsze pomiary [5]. Metoda ta pomaga jednak uniknąć wprowadzenia endoskopu w obszary funkcjonalnie ważne, a co za tym idzie uniknąć powikłań, które stwierdzono w badanym materiale w 1 przypadku $[5,7,18]$.

Fenestrację ściany torbieli należy wykonywać w miejscu pozbawionym naczyń. Oertel i wsp. podają dokładne instrukcje, polecając pole ok. 5-10 mm do tyłu od otworu Monroe, w połowie drogi między ciałem modzelowatym a sklepieniem. Przez miejsce to wg tych autorów zazwyczaj nie drenują żyły przegrodowe, co pozwala uniknąć powikłań. Jest to również dogodny punkt, by przeprowadzić przezeń endoskop w celu 


\section{CONCLUSIONS}

1. The most common and characteristic symptoms reported by patients with the syndrome of expanding septum pellucidum cyst are headache, dizziness and nausea. Headache is located in both sides in the frontal and temporal area and/or behind the eyes, has a distending nature and is accompanied by nausea and vomiting. The most common clinical symptoms of the expanding septum pellucidum cyst syndrome are vomiting and disorders of recent memory. These symptoms tend to increase in severity over time.

2. Symptoms associated with the septum pellucidum cyst develop along with the increase in the transverse dimension of the cyst identified on radiographic examinations. They increase in severity when the distance between the cyst wall and the caput of the caudal nucleus decreases. Changes in the width of ventricles do not affect the dynamics of symptoms in patients with the expanding septum pellucidum cyst syndrome.

3. Carried out observations indicated that the onset of the expanding septum pellucidum cyst syndrome is determined by the valve mechanism causing one-way flow of cerebro-spinal fluid (into the cavum), hence the expanding nature of the cyst. Further research to identify factors involved in this mechanism is reasonable.

4. Fenestration of the cyst reduces its width, increases the thickness of its wall and resolves preoperative clinical symptoms. Endoscopic fenestration of the expanding septum pellucidum cyst is a low-risk, minimally-invasive and highly efficient procedure and therefore should be considered as the method of choice in the treatment of this pathological condition. Endoscopic fenestration is also a valuable tool for the observation of the morphology and dynamics of the cyst under in vivo conditions and should be treated as an investigative method. oceny ścian wewnętrznych torbieli i wykonania fenestracji po drugiej stronie [18]. W badanych przypadkach w Klinice Neurochirurgii PUM stosowano technikę fenestracji 5-10 mm do przodu od otworu Monroe. W opisywanym materiale było to miejsce pozbawione drenujących żył i dogodniejsze z uwagi na możliwość wglądu we wszystkie newralgiczne struktury danego obszaru (otwór Monroe, ściana komory, jądro ogoniaste).

\section{WNIOSKI}

1. Najczęstszymi objawami podmiotowymi charakterystycznymi dla zespołu wypierającej torbieli przegrody przeźroczystej są bóle i zawroty głowy oraz towarzyszące im nudności. Bóle głowy zlokalizowane są w obu okolicach czołowo-skroniowych oraz za gałkami ocznymi. Mają one charakter wypierający i rozsadzający, z towarzyszącymi nudnościami i wymiotami. Najczęstszymi objawami przedmiotowymi zespołu wypierającej torbieli przegrody przeźroczystej są wymioty oraz zaburzenia pamięci świeżej. Mają one tendencje do nasilania się w czasie.

2. Objawy towarzyszące torbieli przegrody przeźroczystej rozwijają się wraz ze stwierdzanym w badaniach radiologicznych powiększeniem się jej wymiaru poprzecznego. Nasilają się one w trakcie zmniejszania się odległości ściany torbieli od głowy jadra ogoniastego. Zmiany szerokości komór nie mają związku z dynamiką objawów zespołu wypierającej torbieli przegrody przeźroczystej.

3. Przeprowadzone obserwacje wskazują, że zespół wypierającej torbieli przegrody przeźroczystej rozwija się poprzez mechanizm zastawkowy prowadzący do przepływu płynu mózgowo-rdzeniowego jedynie w kierunku do wnętrza jamy, co nadaje jej charakter wypierający. Określenie czynników prowadzących do powstania powyższego mechanizmu powoduje dalsze badania zasadnymi.

4. Operacyjne otwarcie torbieli prowadzi do zmniejszenia się jej szerokości i pogrubienia ścian oraz ustąpienia przedoperacyjnych objawów klinicznych. Endoskopowa fenestracja wypierającej torbieli przegrody przeźroczystej jest obarczona niewielkim ryzykiem oraz małą inwazyjnością przy dużej skuteczności, dlatego też wydaje się ona metodą z wyboru w leczeniu tej patologii. Ze względu na walor obserwacji morfologii i dynamiki torbieli w warunkach in vivo, powinna być traktowana również jako metoda poznawcza.

\section{REFERENCES / PIŚMIENNICTWO}

1. Kocer N., Kantarci F., Mihmalli I., Islak C., Cokyuksel O.: Spontaneous regression of a cyst of the cavum septi pellucidi. Neuroradiology. 2000, 42, 360-362.

2. Pearce Z.M.S.: Some observations on the septum pellucidum. Eur Neurol. 2008, 59, 332-334.

3. Sencer A., Sencer S., Turantan I., Devecioglu O.: Cerebrospinal fluid dynamics of the cava septi pellucidi and vergae. Case report. J Neurosurg. $2001,94,127-129$
4. Tubbs R.S., Krishnamurthy S., Verma K., Shoja M.M., Loukas M., Mortazavi M.M. et al: Cavum velum interpositum, cavum septum pellucidum and cavum vergae: a review. Childs Nerv Syst. 2011, 27, 1927-1930.

5. Chiu C.D., Huang W.C., Huang M.C., Wang S.J., Shih Y.H., Lee L.S.: Navigator system-assisted endoscopic fenestration of a symptomatic cyst in the septum pellucidum - technique and cases report. Clin Neurol Neurosurg. $2005,107,337-341$ 
6. Gangemi M., Maiuri F., Cappabianca P., Alafaci C., Divitiis O., Tomasello F. et al.: Endoscopic fenestration of symptomatic septum pellucidum cysts: three case reports with discussion on the approaches and technique. Minim Invasive Neurosurg. 2002, 45, 105-108.

7. Meng H., Feng H., Le F., Lu J.Y.: Neuroendoscopic management of symptomatic septum pellucidum cysts. Neurosurgery. 2006, 59, 278-283.

8. Bochenek A., Reicher M.: Układ nerwowy ośrodkowy. Kresomózgowie. In: Anatomia człowieka. Podręcznik dla studentów i lekarzy. Ed. M. Reicher. PZWL, Warszawa 1963, T. 6, 296-312.

9. Gorczyca P.W., Matysiakiewicz J.A.: Zaburzenia psychiczne u chorych z torbielą przegrody przezroczystej: opis dwu przypadków. Post Psychiat Neurol. 2000, 9, Suppl. 3, 35-38.

10. Kojder I., Niezabitowski K.: Rozszczepienie przemieszczenia bocznego rogów czołowych i przegrody przeźroczystej mózgu jako wskaźnik dynamiki procesów wypierających płata skroniowego. Pol Przegl Radiol. 1986, 50, 133-136.

11. Aldur M.M., Gurcan F., Basar R., Aksit M.D.: Frequency of septum pellucidum anomales in non -psychotic poulation: a magnetic resonance imaging study. Surg Radiol Anat. 1999, 21, 119-123.

12. Fratzoglou M., Grunert P., Leite dos Santos A., Hwang P., Fries G.: Symptomatic cysts of the cavum septi pellucidi and cavum vergae: the role of endoscopic neurosurgery in the treatment of four consecutive cases. Minim Invasive Neurosurg. 2003, 46, 243-249.

13. Jakuszkowiak K., Szeliga J., Cubała W.J., Radziwiłłowicz P., Afeltowicz Z., Czarnowska M.: Zespół paranoidalny ze współistniejącą torbielą przegrody przeźroczystej: psychiatryczne i psychologiczne studium przypadku. Wiad Psychiat. 2003, 6, 211-215.

14. Byrd S.E., Harwood-Nash D.C., Fitz C.R.: Absence of the corpus callosum: computed tomographic evaluation in infants and children. J Can Assoc Radiol. 1978, 29, 108-112.

15. Radziwiłłowicz P., Radziwiłłowicz W., Krystoforska A., Cubała W.J.: Zespół anankastyczno-depresyjny u chorego z torbielą przegrody przeźroczystej. Psychiatryczne i psychologiczne studium przypadku. Psychiat Pol 2003, 37, 463-475.

16. Lancon J.A., Haines D.E., Raila F.A., Parent A.D., Vedanarayanan V.V.: Expanding cyst of the septum pellucidum. Case report. J Neurosurg. 1996 85, 1127-1134.

17. Lewis S.W., Mezey G.C.: Clinical correlates of septum pellucidum cavities: an unusual association with psychosis. Psychol Med. 1985, 15, 43-54.

18. Oertel J.M., Schroeder H.W., Gaab M.R.: Endoscopic stomy of the septum pellucidum: indications, technique, and results. Neurosurgery. 2009 64, 482-493.

19. Liss L., Mervis L.: The ependymal lining of the cavum septi pellucidi: a histological and histochemical study. J Neuropathol Exp Neurol. 1964, 23 355-367.

20. Bikmaz K., Dinc C., Cakabay M., Iplikcioglu A.C.: Epidermoid cyst of the cavum septum pellucidum. Acta Neurochir (Wien). 2007, 149, 1271-1272.

21. Silbert P.L., Gubbay S.S., Vaughan R.J.: Cavum septum pellucidum and obstructive hydrocephalus. J Neurol Neurosurg Psychiatry. 1993, 56 820-822.

22. Raybaud C.: The corpus callosum, the other great forebrain commissures and the septum pellucidum: anatomy, development, and malformation. Neuroradiology. 2010, 52, 447-477.

23. Garza-Mercado R.: Giant cyst of the septum pellucidum. Case report. J Neurosurg. 1981, 55, 646-650.

24. Jackowski A., Kulshresta M., Sgouros S.: Laser-assisted flexible endoscopic fenestration of giant cyst of the septum pellucidum. Br J Neurosurg. 1995, 9, 527-532.

25. Shaw C.M., Alvord E.C.: Cava septi pellucidi et vergae: their normal and pathological states. Brain. 1969, 92, 213-224.

26. Fredriksson L., Nilsson I., Su E.J., Andrae J., Ding H., Betsholtz C. et al.: Platelet-derived growth factor C deficiency in C57BL/6 mice leads to abnormal cerebral vascularization, loss of neuroependymal integrity, and ventricular abnormalities. Am J Pathol. 2012, 180, 1136-1144.

27. Bronshtein M., Weiner Z.: Prenatal diagnosis of dilated cava septi pellucidi et vergae: associated anomalies, differential diagnosis and pregnancy outcome. Obstet Gynecol. 1992, 80, 838-842.

28. Ronsin E., Grosskopf D., Perre J.: Morphology and immunihistochemistry of a symptomatic septum pellucidum cavum Vergae cyst in man. Acta Neurochir (Wien). 1997, 139, 366-372.
29. Findler G., Hoffman H.J.: Intracranial midline cyst in association with myelodysplasia. Neurosurgery. 1980, 7, 521-524.

30. Kaciński M., Kubik A., Pakszys M., Gergont A., Prajsner B.: Rozwój badań nad torbielą przegrody przeźroczystej u dzieci i dorosłych. Przegl Lek. 2001, 58, 147-150.

31. Kaciński M., Prajsner B., Kubik A.: Ocena psychologiczna dzieci z torbielą przegrody przeźroczystej. Wyniki wstępne. Neurol Dziec. 2002, 11, 41-48.

32. Kaciński M., Prajsner B., Kubik A., Gergont A., Jaworek M.: Wyniki oceny psychologicznej dzieci z torbielą przegrody przeźroczystej. Przegl Lek. 2004, 61, 486-490.

33. Rossitch E., Wilkins R.H.: Developmental midline intracranial cysts. In: Neurosurgery. R.H. Wilkins, S.S. Rengachary. McGraw-Hill, New York 1996, 3, 3707-3708.

34. Chen C.J.: Expanding septum pellucidum cyst due to a traumatic ventriculoperitoneal shunt. Neuroradiology. 1999, 41, 567-569.

35. Frattalone A.R., Neely E.T.: Positional headache associated with a dilated cyst of the septum pellucidum. Mil Med. 2011, 176, 1202-1203.

36. Hamlat A., Casallo-Quiliano C., Saikali S., Adn M., Brassier M.A., Brassier G.: Huge colloid cyst: case report and review of unusual forms. Acta Neurochir (Wien). 2004, 146, 397-401.

37. Miki T., Wada J., Nakajima N., Inaji T., Akimoto J., Haraoka J.: Operative indications and neuroendoscopic management of symptomatic cysts of the septum pellucidum. Childs Nerv Syst. 2005, 21, 372-381.

38. Mishra G.P., Sharma R.R., Musa M.M., Pawar S.J.: Endodermal cyst of septum pellucidum and pregnancy: a case report. Surg Neurol. 2000, 53, 583-585.

39. Monaco P., Filippi S., Mascari C., Godano U.: Symptomatic cyst of the septum pellucidum treated by stereotactic intraventricular drainage. Stereotact Funct Neurosurg. 1995, 64, 134-138.

40. Nishijima Y., Fujimura M., Nagamatsu K., Kohama M., Tominaga T.: Neuroendoscopic management of symptomatic septum pellucidum cavum Vergae cyst using a high-definition flexible endoscopic system. Case report. Neurol Med Chir (Tokyo). 2009, 49, 549-552.

41. Rakic P., Yakovlev P.I.: Develompent of the corpus callosum and cavum septi in man. J Comp Neurol. 1968, 132, 45-72.

42. Tuchman A., Kalhorn S.P., Mikolaenko I., WisoffJ.H.: Cystic choroid plexus papilloma in the cavum septum pellucidum. Case report. J Neurosurg Pediatr. 2009, 4, 580-583.

43. Xiong J., Liu Y., Chu S.G., Chen H., Chen H.X., Mao Y. et al.: Dysembryoplastic neuroepithelial tumor-like neoplasm of the septum pellucidum: review of 2 cases with chromosome 1p/19q and IDH1 analysis. Clin Neuropathol. 2012, 31, 31-38.

44. Yonezawa H., Shinsato Y., Obara S., Oyoshi T., Hirano H., Kitajima S. et al:: Germinoma with syncytiotrophoblastic giant cells arising in the corpus callosum - case report. Neurol Med Chir (Tokyo). 2010, 50, 588-591.

45. Bayar M.A., Gokcek C., Gokcek A., Edebali N., Buharali Z.: Giant cyst of the cavum septi pellucidi and cavum Vergae with posterior cranial fossa extension: case report. Neuroradiology. 1996, 38, Suppl. 1, S187-189.

46. Lancon J.A., Haines D.E., Lewis A.I., Parent A.D.: Endoscopic treatment of symptomatic septum pellucidum cysts: with some preliminary observations on the ultrastructure of the cyst wall: two technical case reports. Neurosurgery. 1999, 45, 1251-1257.

47. Sharma R.R., Ravi R.R., Gurusinghe N.T., Coutinho C., Mahapatra A.K., Sousa J. et al:: Cranio-spinal enterogenous cysts: clinico-radiological analysis in a series of ten cases. J Clin Neurosci. 2001, 8, 133-139.

48. Weyerbrock A., Mainprize T., Rutka J.T.: Endoscopic fenestration of a symptomatic cavum septum pellucidum: technical case report. Neurosurgery. 2006, 59, Suppl. 2, ONS-49.

49. Wester K., Krakenes J., Moen G.: Expanding cava septi pellucidi and cava Vergae in children: report of three cases. Neurosurgery. 1995, 37, 134-137.

50. Wester K., Pedersen P.H., Larsen J.L., Waaler P.E.: Dynamic aspects of expanding cava septi pellucidi et Vergae. Acta Neurochir (Wien). 1990, 104, 147-150.

51. Richards P.G., Hatfield R., Grant H.C.: Brain damage from boxing. J Neurosurg. 1986, 65, 723.

52. Neciga E.G., Peralta A.G., Polaina M., Sureda B., Bautista J.: Cyst of the septum pellucidum and Korsakoff's psychosis. Eur Neurol. 1989, 29, 99-101.

53. Aoki N.: Brain damage from boxing. J Neurosurg. 1986, 64, 829-930. 
54. Wang K.C., Fuh J.L., Lirng J.F., Huang W.C., Wang S.J.: Headache profiles in patients with a dilatated cyst of the cavum septi pellucidi. Cephalalgia. 2004, 24, 867-874

55. Kansu T., Bertan V.: Fifth ventricle with bitemporal hemianopsia. J Neurosurg. 1980, 52, 276-278.

56. Hong Y., Chen S., Guo S.X., Zhang J.M.: Spontaneous resolution of a cyst of the septum pellucidum. Am J Med Sci. 2011, 342, 333-335.

57. Bodensteiner J.B., Schaefer G.B.: Wide cavum septum pellucidum: A marker of disturbed brain development. Pediatr Neurol. 1990, 6, 391-394.
58. Miele V.J., Bailes J.E., Martin N.A.: Participation in contact or collision sports in athletes with epilepsy, genetic risk factors, structural brain lesions or history of craniotomy. Neurosurg Focus. 2006, 21, E9.

59. Sarwar M.: The septum pellucidum: normal and abnormal. AJNR. 1989, 10, 989-1005.

60. Sagan L.: Wartość wspomagania endoskopowego w leczeniu i ocenie wodogłowia w przypadkach wtórnej niedostateczności funkcji układu zastawkowego. Rozprawa habilitacyjna. Wyd. Pom. Akad. Med. w Szczecinie, Szczecin 2009. 